\title{
Manejo de defectos óseos anteroposteriores en el frente estético
}

\section{Management of anteroposterior bone defects in aesthetic restoration of the front teeth}

\author{
J. Caubet Biayna , I. Heras Rincón², J. Sánchez Mayoral', M. Morey Mas³, J.I. Iriarte Ortabe
}

Resumen: Objetivo: Desarrollar un protocolo clínico para el manejo de defectos óseos anteroposteriores en el frente estético para la posterior rehabilitación con implantes osteointegrados.

Material y método: Repasamos conceptos anatómicos que caracterizan el frente estético, de colocación y relación tridimensional de los implantes y hacemos una revisión bibliográfica actualizada sobre las distintas técnicas reconstructivas óseas y de partes blandas centradas en el frente estético. Recogemos nuestra experiencia tras 8 años de manejo con distintos tipos de injertos en el manejo de estos defectos.

Resultados: En función de la magnitud del defecto óseo (pequeño que no compromete la colocación del implante, de una pared que compromete la colocación del implante o de dos o tres paredes) y del biotipo periodontal del paciente exponemos un protocolo de tratamiento de defectos óseos para la rehabilitación con implantes osteointegrados en el frente estético.

Conclusiones: En el sector estético deben tomarse las máximas precauciones en la colocación de cualquier implante. Estas precauciones deben ser aún mayores en los casos de injertos óseos. El adecuado manejo de los injertos óseos nos permitirá colocar los implantes de modo tridimensional correcto para conseguir resultados estéticos en las restauraciones.

Palabras clave: Estética; Zona; Injerto; Defecto; Óseo.

Recibido: 08.10 .08

Aceptado: 02.03.09

1 Cirujano Oral y Maxilofacial Práctica privada GBCOM. Palma de Mallorca. España.

2 Médico Residente. Servicio de Cirugía Oral y Maxilofacial. Hospital 12 Octubre Madrid. España

3 Médico adjunto. Servicio de COMF. Hospital Universitario Son Dureta. P. de Mallorca. España.

4 Jefe Servicio de COMF. Hospital Universitario Son Dureta. P. de Mallorca. España.

\begin{abstract}
Objective: Development of a clinical protocol for the management of anteroposterior bone defects in the front teeth followed by later rehabilitation with osseointegrated implants.

Material and method: The anatomic concepts that characterize the front teeth and the placement and three-dimensional relations of implants were reviewed. Recent literature on bone and soft-tissue reconstruction techniques for the front teeth was reviewed. We present our 8-year experience in managing these defects with different types of grafts.

Results: A protocol for the treatment of bone defects for rehabilitation of the front teeth with osseointegrated implants is described that depends on the magnitude of the bone defect (small defects that do not jeopardize implant placement, single-wall defects that jeopardize implant placement, or two or three-wall defects) and the patient's periodontal biotype.

Conclusions: In aesthetic restoration, maximum precautions must be taken in placing any implant. These precautions must be even greater when bone grafts are required. Proper bone graft management makes it possible to correctly place the implants threedimensionally to achieve acceptable aesthetic results for restorations.
\end{abstract}

Key words: Aesthetic; Zone; Graft; Defect; Bone.

\section{Correspondencia:}

Jorge Caubet Biayna

GBCOM Clínica Juaneda

C/ Company, 30

07014 Palma de Mallorca. España

E-mail: jcaubet@telefonica.net 


\section{Introducción}

La pérdida de hueso es un problema que dificulta o impide la colocación de implantes. En este artículo vamos a discutir el manejo de esos defectos óseos en el sector estético para la posterior colocación de implantes osteointegrados. Muchas pueden ser las causas de la pérdida de hueso, aunque una simple extracción y el uso prótesis dentales pueden aumentar la resorción ósea provocando grandes deformidades. En éstas áreas el objetivo no implica sólo la osteointegración del implante. El resultado final tiene que ser una restauración implanto-soportada rodeada de hueso y tejidos blandos de calidad en armonía con la dentición existente. Para conseguir un resultado estético predecible necesitamos conocer todos los factores que pueden influir en el resultado final. Un error en el manejo de las partes blandas o en la posición del implante, a pesar de disponer de suficiente cantidad de hueso y partes blandas, puede llevarnos a un fracaso desde el punto de vista estético. Por eso vamos a:

- Analizar una serie conceptos anatómicos antes de comenzar el tratamiento.

- Repasar las distintas técnicas reconstructivas óseas.

- Desarrollar un protocolo clínico para el manejo de defectos óseos en el sector estético.

- Ilustrar el manejo de cada uno de los tipos de defectos óseos con un caso clínico.

\section{Conceptos anatómicos en el frente estético}

\section{Línea de sonrisa}

El estudio de la línea de sonrisa es el factor más importante en la evaluación de la estética dental del paciente. La relación entre los dientes y la línea de la sonrisa es el punto de partida para la reconstrucción dental en el sector estético. La posición del labio debe ser evaluada en reposo, en conversación, en una sonrisa moderada y relajada y en una sonrisa intensa. Debemos evaluar la exposición dentogingival cuando el paciente está completamente relajado y los labios están posicionados naturalmente. La línea de sonrisa media se describe como aquella en la que se muestra un $75-100 \%$ del incisivo central y de la encía interproximal. Una línea de sonrisa alta es aquella en la que se muestra más cantidad de encía. Una línea de sonrisa baja es cuando se muestra menos del $75 \%$ del incisivo central. ${ }^{1}$ La exposición incisal media con los labios en reposo es de 1,91 $\mathrm{mm}$ en hombres y de 3,40 $\mathrm{mm}$ en mujeres. Una exposición gingival superior a $3 \mathrm{~mm}$ se considera una sonrisa gingival (Fig. 1). Los casos de reconstrucción ósea en el frente estético con una línea de sonrisa alta deben ser considerados de alto riesgo. tion of the implant. The final outcome has to be an implantsupported restoration surrounded by good quality bone and soft tissues that harmonize with the existing dentition. In order to achieve predictable aesthetic results, we need to know all the factors that can influence outcome. An error in soft tissue management or implant position, despite the sufficiency of the bone and soft tissues, can lead to aesthetic failure. For that reason we will:

- Analyze the anatomic concepts before beginning treatment,

- Review different bone reconstruction techniques,

- Develop a clinical protocol for the aesthetic management of bone defects,

- Illustrate the management of each type of bone defect with a clinical case.

\section{Anatomic concepts in aesthetic restoration of the front teeth}

\section{Smile line}

The study of the smile line is the most important element in evaluating the patient's dental aesthetics. The relation between the teeth and the smile line is the point of departure for aesthetic reconstruction of the front teeth. Lip position must be evaluated at rest, while speaking, with a moderately relaxed smile, and with a full smile. We must evaluate the exposure of the teeth and gums when the patient is completely relaxed and lips are positioned naturally. The mean smile line is described as showing $75-100 \%$ of the central incisors and interproximal papillae. A high smile line exposes more gum. A low smile line exposes less than $75 \%$ of the central incisor. ${ }^{1}$ The mean incisor exposure with the lips at rest is $1.91 \mathrm{~mm}$ in men and $3.40 \mathrm{~mm}$ in women. Exposure of more than $3 \mathrm{~mm}$ of gum is considered to be a "gummy" smile (Fig. 1). Cases of reconstruction of the front teeth in patients with a high smile line must be considered high risk. 


\section{Biotipo periodontal y morfología del diente}

El biotipo periodontal es uno de los factores más importantes para determinar el pronóstico del tratamiento con implantes en el sector estético. En función del biotipo deberemos personalizar el plan de tratamiento para conseguir un resultado estético y duradero. De este modo, conociendo el biotipo periodontal y haciendo un análisis del mismo podremos establecer expectativas realistas en el resultado del plan de tratamiento.

Se han descrito dos biotipos periodontales, los cuales se encuentran relacionados íntimamente con la morfología del diente (Figs. 2 y 3):2

1. Biotipo fino-festoneado: con una arquitectura periodontal delicada, friable y con poco tejido blando. Se asocia a una morfología dental específica con coronas anatómicamente triangulares con pequeños contactos interdentales en el tercio incisal y papilas largas y finas. Responde a las intervenciones quirúrgicas y prostodóncicas con recesión y migración apical del anclaje periodontal y pérdida del volumen alveolar subyacente que da lugar a un espacio vacío conocido como "triángulo negro". Bajo un biotipo periodontal fino suele existir una cortical ósea vestibular fina con tendencia a formar defectos óseos secundarios a la remodelación y reabsorción del hueso que se produce después de una exodoncia o del fresado para la colocación del implante.

El equipo implantológico (cirujano-prostodoncista-técnico de laboratorio) debe aunar esfuerzos para preservar el tejido óseo y blando utilizando técnicas quirúrgicas poco agresivas y procedimientos restauradores adecuados. En el caso de exodoncias en pacientes con biotipo periodontal fino se recomienda utilizar técnicas de preservación de la cresta alveolar como la erupción ortodóncica del diente, preservación del alvéolo y la regeneración ósea guiada, ${ }^{3}$ así como de refuerzo de los tejidos blandos como injertos de tejido conectivo. ${ }^{4}$

2. Biotipo grueso-plano: en este biotipo periodontal el tejido blando es denso y fibrótico con abundancia de tejido insertado. El hueso subyacente es grueso y denso. Las coronas dentales son cuadradas con convexidad en el tercio cervical. Los puntos de contacto entre las coronas son largos y a menudo se extienden hasta la zona del tercio cervical. Las papilas interdentales son cortas comparadas con las existentes en el biotipo fino. En este caso la respuesta a la agresión quirúrgica no es la recesión gingival sino la formación de una cicatriz que puede comprometer el resultado final tanto desde un punto de vista estético como funcional.
Periodontal biotype

and tooth morphology

The periodontal biotype is one of the most important factors in evaluating the prognosis of aesthetic restoration of the front teeth with implants. Depending on the biotype, the treatment plan has to be personalized to achieve an acceptable and lasting aesthetic result. Knowledge and analysis of the periodontal biotype allows us to establish realistic expectations for the outcome of the treatment plan.

Two periodontal biotypes that are related intimately to tooth morphology have been described ${ }^{2}$ (Figs. 2 and 3):

1. Thin scalloped periodontal biotype: In this biotype the periodontal architecture is delicate and friable, with scant soft tissue. The thin periodontal biotype is associated to a specific dental morphology with anatomically triangular crowns, small interdental contact surfaces in the incisal third, and long thin papillae. The thin periodontal biotype responds to surgical and prosthodontic interventions with gum recession, apical migration of the periodontal anchorage, and loss of underlying alveolar volume, which results in an empty space known as a "black triangle". The thin periodontal biotype usually is accompanied by thin vestibular cortical bone with a tendency to form bone defects secondary to bone remodeling and resorption after tooth extraction or milling for implant placement.

The implantology team (surgeon, prosthodontist, and laboratory technician) have to coordinate their efforts to preserve the bone and soft tissue by using less aggressive surgical techniques and appropriate restoration procedures. In tooth extractions in patients with a thin periodontal biotype, it is recommended that alveolar crest preservation techniques be used, such as orthodontic tooth eruption, alveolar preservation, and guided bone regeneration, ${ }^{3}$ as well as soft tissue reinforcement, such as connective tissue grafts. ${ }^{4}$

2. Thick flat periodontal biotype: In this periodontal biotype, the soft tissue is dense and fibrotic, with abundant inserted tissue. The underlying bone is thick and dense. The dental crowns are square and convex in the cervical third. The contact points between crowns are long and often extend to the zone of the cervical third. Interdental papillae are short compared to the thin periodontal biotype. In this case, the 


\section{Distancia entre implantes-dientes}

El conocimiento de las distancias entre implantes y entre diente e implantes es fundamental para conseguir buenos resultados estéticos. Por otra parte la correcta ubicación tridimensional (mesio-distal, vestibulo-palatal y ápico-coronal) del implante en el hueso permitirá un resultado estético adecuado así como estable (Tabla 1).

Mesio-distalmente, para mantener la integridad de la papila y conseguir resultados estéticos óptimos, la distancia entre un implante y un diente vecino no debe ser inferior a 1.5 milímetros y al menos de 3 milímetros entre dos implantes.5,6 (Figs. 4 y 5). Cuando estos dos implantes reemplazan a los dos incisivos centrales se recomiendan al menos 4 milímetros. ${ }^{3}$ En el sentido vestíbulo-palatal deben preservarse al menos 2 milímetros de tabla vestibular, de manera que la superficie externa del implante quede situada 2 milímetros por palatino de una línea imaginaria delimitada por el arco formado por la superficie vestibular de los dientes vecinos (Fig. 6a) y con el centro del implante 2 milímetros hacia palatino de esta línea imaginaria. Eso equivale a que el eje del implante emerja por el cíngulo del diente restaurado. Finalmente, en sentido ápico-coronal el implante debería quedar 3 milímetros por encima de la línea amelocementaria. 3,7-9 Es lo que Buser describió como las zonas de confort en las tres dimensiones del espacio para la correcta ubicación de un implante dental en la zona estética (Fig. 6b). ${ }^{10}$

\section{Técnicas reconstructivas óseas}

\section{Regeneración ósea guiada (ROG)}

Se define como aquel conjunto de técnicas que favorecen la formación ósea por medio de la protección de un defecto óseo contra la invasión de tejidos no osteogénicos. Para ello se sirven de membranas con una determinada permeabilidad y compatibilidad tisular, que actúan como barreras protegiendo el defecto de la invasión de de tejido fibroconectivo originado en la mucosa gingival.

La membrana debe ser biocompatible, impermeable, debe mantener el espacio para que se produzca una regeneración estable, debe ser manejable e integrarse con el tejido conectivo circundante.

Estas membranas pueden ser reabsorbibles y no reabsorbibles.

Las membranas no reabsorbibles más utilizadas son la de Goretex (Politetrafluoroetileno expandido, e-PTFE). La utilización de estas membranas está bien descrita por Simion (Tabla 2), ${ }^{11}$ deben estar response to surgical aggression is not gum recession but scar formation that can jeopardize the aesthetic and functional outcome.

Distance between implants and teeth

Knowledge of the implant-toimplant and implant-to-tooth distances is fundamental for achieving good aesthetic results. Correct three-dimensional placement (mesio-distal, vestibulo-palatal, and apico-coronal) of the implant in the bone will make an acceptable stable outcome possible (Table 1). The mesio-distal distance between an implant and a neighboring tooth should be at least $1.5 \mathrm{~mm}$ to maintain papilla integrity and achieve optimal aesthetic results. There should be at least 3 $\mathrm{mm}$ between adjacent implants 5,6 (Figs. 4 and 5). When two implants replace the two central incisors, the distance between implants should be at least $4 \mathrm{~mm} \cdot{ }^{3}$ At least $2 \mathrm{~mm}$ of vestibular table must be preserved on the vestibulo-palatal side so that the external surface of the implant is situated $2 \mathrm{~mm}$ palatally from an imaginary line delimited by the arc formed by the vestibular surface of the neighboring teeth (Fig. 6a) and the center of the implant is $2 \mathrm{~mm}$ palatally to this imaginary line. This is equivalent to the implant axis emerging from the basal ridge of the restored tooth. Finally, the implant should be $3 \mathrm{~mm}$ above the amelo-cementum junction in apicocoronal direction. $3,7-9$ This is what Buser described as the comfort zone in the three spatial dimensions for correct implant placement in aesthetic restoration of the front teeth ${ }^{10}$ (Fig. 6b).

\section{Reconstructive bone techniques}

\section{Guided bone regeneration (GBR)}

Guided bone regeneration is a set of techniques that favor bone formation by protecting a bone defect against 
fijadas mediante microtornillos o chinchetas, deben estar alejadas de los dientes adyacentes y deben tener bajo ellas espacio a regenerar. Se trata de membranas que tienen el inconveniente de tener que ser retiradas al no ser reabsorbibles. Son muy sensibles a la técnica quirúrgica y deben estar cubiertas por un colgajo de espesor total. Pueden Ilevar un refuerzo de titanio para resistir mejor la presión del tejido blando (Fig. 7) (Tabla 2). Una de las complicaciones, ${ }^{12}$ que más frecuentes de estas membranas, es la exposición y consiguiente infección que obliga a la retirada de las mismas. Simion refiere una menor tasa de regeneración ósea cuando existe contaminación y exposición de la misma que cuando no se expone $(41,6$ vs $96,6 \%)$ y confirma con estudios a largo plazo que el hueso conseguido con técnicas de ROG con este tipo de membranas responde a la colocación del implante del mismo modo que lo haría en hueso nativo maduro. ${ }^{13}$

Las membranas reabsorbibles suelen ser de colágeno de origen bovino o porcino. Tienen la ventaja de ser más biocompatibles, con una menor tasa de exposición. ${ }^{14}$ No necesitan fijación con tornillos ni ser retiradasm por su naturaleza reabsorbible. A diferencia de las membranas de e-PTFE, la resistencia a los tejidos blandos es más difícil de mantener. Estas membranas pueden utilizarse para cubrir injertos óseos tanto corticales como particulados. ${ }^{15}$ En estos casos ayudan a que se produzca una menor reabsorción de los injertos. ${ }^{16,17}$ Estas membranas no reabsorbibles también pueden utilizarse en perforaciones en la membrana Schneideriana del seno maxilar. ${ }^{18}$

El efecto barrera es más difícil de conseguir con las membranas reabsorbibles, por lo que al utilizar estas membranas se recomienda colocar material de injerto bajo ellas. ${ }^{19}$

La literatura no muestra diferencias estadísticamente significativas entre el empleo de membranas reabsorbibles y no reabsorbibles en general,20,21 aunque está publicado un mayor volumen de regeneración ósea con membranas no reabsorbibles alrededor de implantes colocados post-exodoncia. ${ }^{22}$ En el trabajo publicado por Chia-

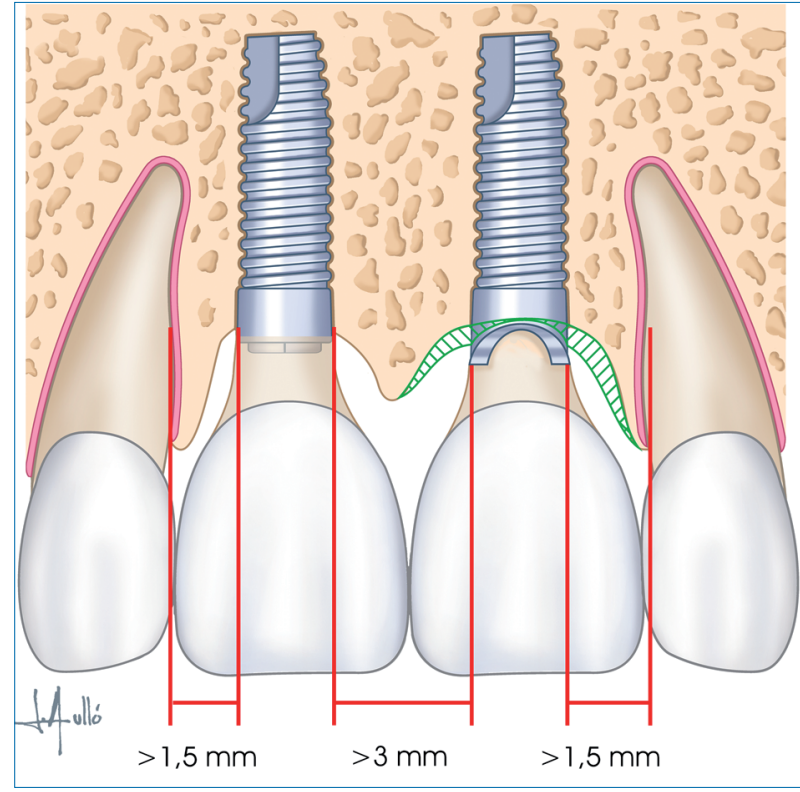

Figura 5. Distancia entre implantes: debe ser $>3 \mathrm{~mm}$.

Figure 5. The distance between implants should be $>3 \mathrm{~mm}$.

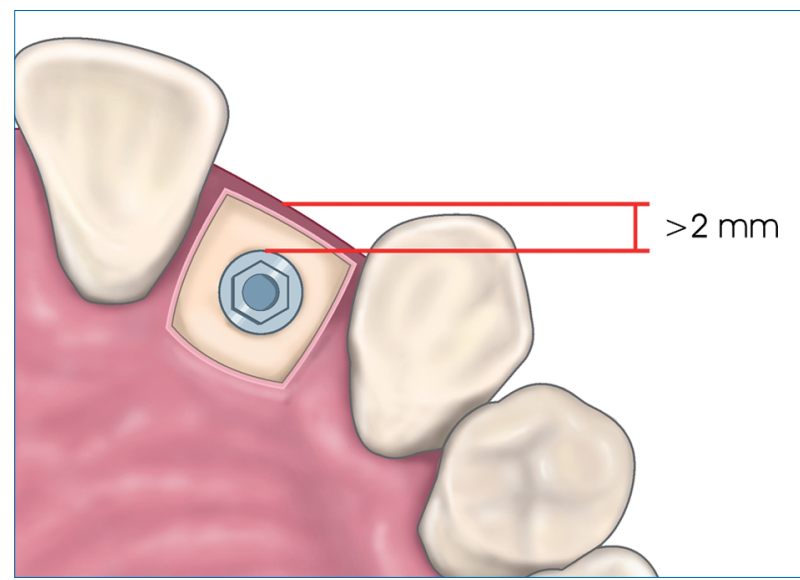

Figura 6a. El implante debe tener asegurada una protección ósea vestibular $>2 \mathrm{~mm}$.

Figure $6 a$. The implant should have vestibular bone protection of $>2 \mathrm{~mm}$.

Tabla 2. Membrana de e-PTFE

Fijadas con tornillos

Alejadas de los dientes

Colgajo de espesor total

Muy sensibles a la técnica quirúrgica

No reabsorbibles

Table 2. e-PTFE membrane

Attached with screws

Separated from teeth

Full-thickness flap

Very sensitive to surgical technique

Nonabsorbable the invasion of nonosteogenic tissue. GBR is implemented using membranes with a certain permeability and tissue compatibility, which act as barriers to protect the defect against the invasion of fibroconnective tissue originating in the gingival mucosa.

The membrane must be biocompatible and impermeable; it must maintain the space so that stable regeneration can take place and It must be manageable and integrate with the surrounding connective tissue.

Membranes can be either absorbable or nonabsorbable. The most widely used nonabsorbable membranes are Gore-Tex (expanded poly (tetrafluoroethylene), ePTFE). Use of these membranes has been well described by Simion ${ }^{11}$ (Table 2). Membranes should be attached using microscrews or tacks, separated from the adjacent teeth and leaving space below the teeth for regeneration. These membranes have the drawback that they must be removed because they are not absorbable. They are very sensitive to the surgical technique and must be covered by a full-thickness flap. They can be reinforced with titanium to better resist soft-tissue pressure (Fig. 7) (Table 2). One of the most frequent complications $^{12}$ of these membranes is exposure and infection, which makes it necessary to remove the membrane. Simion reports a lower rate of bone regeneration when bone exposure and contamination occur than in unexposed membranes (41.6 versus $96.6 \%$ ) and has confirmed in long-term studies that the bone obtained with 


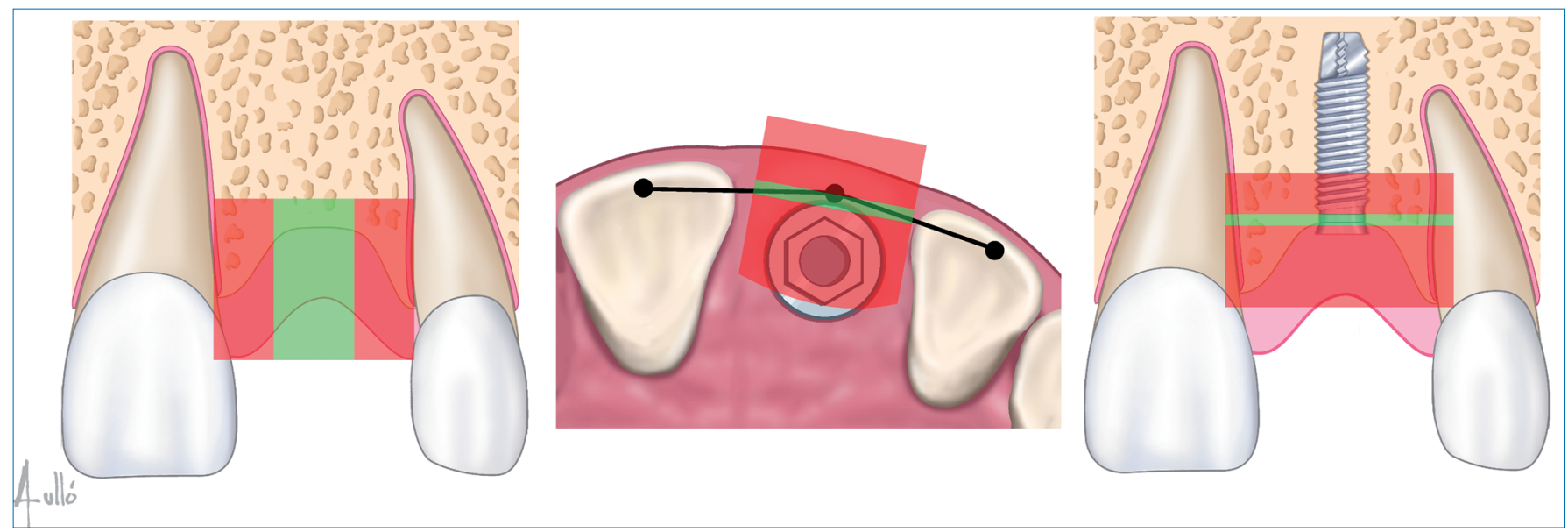

Figura 6b. Zonas de confort en las tres dimensiones del espacio.

Figure $6 \mathrm{~b}$. Comfort zones in the three spatial dimensions.

pasco y cols. se advierte del mayor riesgo de exposición y contaminación de las membranas no reabsorbibles cuando se compara con injertos óseos no cubiertos con membrana. ${ }^{23}$ Está publicado con una leve evidencia una mejor cicatrización con menos infecciones con el uso de membranas reabsorbibles sobre injertos óseos que con membranas no reabsorbibles. ${ }^{24}$

\section{Injertos particulados}

Pueden ser injertos autólogos o

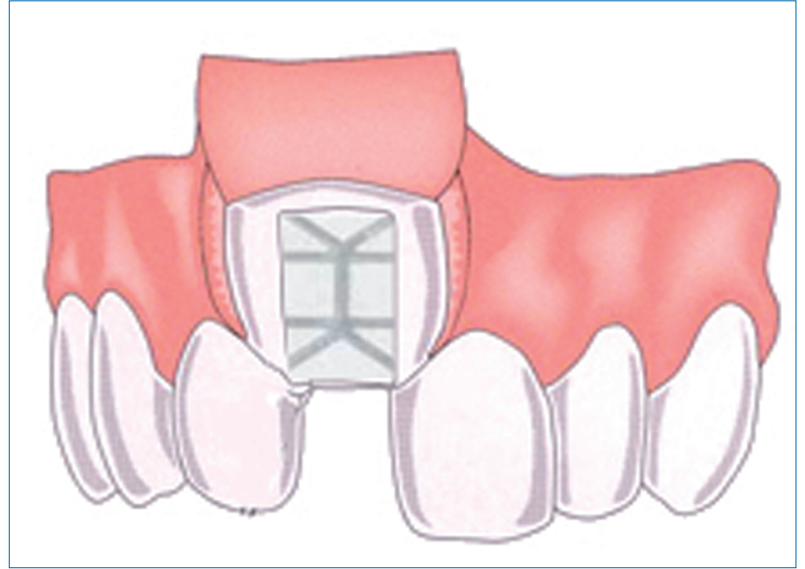

Figura 7. Membrana de Goretex con refuerzo de titanio. Figure 7. Titanium-reinforced Goretex membrane.
GBR techniques and this type of membranes responds to implant placement much as mature native bone does. 13

The absorbable membranes usually are collagen of bovine or porcine origin. They have the advantage of being more biocompatible with a lower rate of exposure. ${ }^{14}$ They do not have to be attached with screws or removed. In contrast with e-PTFE membranes, it is harder to maintain the resistance of absorbable membranes to soft tissues. Absorbable membranes can be used to cover both cortical and particulate bone grafts. 15 In these cases it is helpful if graft absorption is minimized. ${ }^{16,17}$ biomateriales. Se utilizarán en cavidades autorretentivas y la literatura muestra mejores resultados cuando se cubren con una membrana. ${ }^{25}$ La propiedad más importante del hueso autólogo es la osteogenicidad. Además, aporta osteoinducción y osteoconducción.

El injerto particulado autólogo ha sido considerado hasta hace poco por la literatura científica como el "gold-standard", suele obtenerse de zonas intraorales mediante raspadores óseos (de hueso adyacente al defecto óseo, de mentón o arbotante maxilomalar) y es capaz de formar hueso maduro a los 9 meses. ${ }^{26}$ Se ha visto un mayor volumen de hueso regenerado y una mayor sustitución ósea cuando el tamaño de estas partículas es inferior a 2 milímetros cúbicos. ${ }^{27}$

Existen multitud de biomateriales que pueden ser utilizados como injerto particulado. Entre ellos destaca la hidroxiapatita, la más utilizada es la de origen bovino. Los trabajos de Hallman mostraron que al mezclarla con hueso autólogo en proporción 80:20 asociaba sus propiedades osteoconductoras con las propiedades osteogénicas y osteoinductoras del hueso autólogo, permitiendo una regeneración ósea más rápida y fiable sin apenas reabsorción. ${ }^{28}$ ${ }^{30}$ Según esto, el efecto del hueso autólogo no está claro pero parece que reduce el tiempo de cicatrización clásico de 6 meses. ${ }^{31}$ Basán-
Nonabsorbable membranes also can be used in Schneider membrane perforations of the maxillary sinus. ${ }^{18}$

The barrier effect is more difficult to achieve with absorbable membranes so it is recommended that graft material be placed under these membranes. ${ }^{19}$

The literature does not generally show statistically significant differences between the use of absorbable and nonabsorbable membranes, 20,21 but a larger volume of bone regeneration is reported with nonabsorbable membranes in implants placed after tooth extraction.22 In the study reported by Chiapasco et al., there is a greater risk of exposure and contamination with nonabsorbable membranes that with bone grafts not covered with membrane. ${ }^{23}$ Some evidence has been found that healing is better and there are fewer infections when the bone graft is covered by an absorbable membrane than by a nonabsorbable membrane. ${ }^{24}$

\section{Particulate grafts}

Particulate grafts may be either autologous or biomaterials. They are used to fill self-retaining cavities. Better results have been reported in the literature when the graft 
donos en nuestra experiencia clínica, este tiempo de espera para la colocación de los implantes podría reducirse de forma fiable hasta los 4 meses. Del mismo modo, puede ser mezclada con hueso particulado autólogo, pero esta vez en proporción 1:1.32

\section{Injertos corticales}

Siguiendo los criterios publicados por Collins en 1995,33 existen nueve requisitos para obtener éxito en las reconstrucciones con injertos en bloque:

1. El paciente debe tener unas expectativas reales y razonables de lo que se intenta conseguir.

2. Estudio prequirúrgico del caso con montaje de modelos y encerado diagnóstico de la prótesis deseada.

3. Elaboración de una férula quirúrgica.

4. Reconstrucción anatómica del defecto.

5. Fijación rígida del injerto con un mínimo de dos tornillos de osteosíntesis de titanio, asegurándose que exista un contacto íntimo entre el hueso receptor y el injerto.

6. Fijación sólida de los implantes al hueso receptor.

7. El injerto debe ser diseñado de forma que, tras la colocación de los implantes en sus posiciones ideales desde el punto de vista prostodóntico, se pueda se pueda asegurar una cobertura ósea de cada cara del implante por un mínimo de 1,5 milímetros de hueso. Si no se consigue dicho espesor mínimo, es muy probable que la reabsorción del injerto provoque exposición de las espiras del implante. Este punto es especialmente relevante en los injertos colocados en la zona estética donde se ha de conseguir un mínimo de 2 milímetros de cobertura ósea por la cara vestibular.

8. Cierre del colgajo sin tensión. La exposición al medio intraoral es la causa más frecuente de infección y pérdida del injerto.

9. Ausencia de presión de la prótesis provisional sobre la zona injertada.

Los injertos corticales más comúnmente empleados en el sector estético son los de origen intraoral: rama ascendente y mentón. La rama ascendente se asocia con una menor morbilidad que la zona mentoniana. 34,35 Tras la exploración clínica y radiológica y confirmación de la necesidad de un injerto cortical, se realiza un colgajo mucoperióstico de espesor total para exponer el defecto óseo. A continuación se realiza la obtención del injerto utilizando frecuentemente el bisturí piezoeléctrico y se realiza el tallado y adaptación del injerto cortical. El injerto se fija con tornillos de osteosíntesis y los espacios muertos se rellenan con una mezcla de hueso autólogo obtenido con raspador e hidroxiapatita o matriz ósea desmineralizada. Todo el material de injerto se cubre con una membrana reabsorbible de colágeno y se realiza una sutura sin tensión mediante monofilamento de 5 y 6/0.36 Para evitar tensión en la sutura es muy útil realizar una periostiotomía en el lecho receptor del injerto, previa a la obtención del mismo, con idea de que el sangrado secundario a la misma ocurra al principio de la intervención y no al final. El injerto cortical debe estar perfectamente adaptado sin aristas que puedan ocasionar dehiscencias de sutura ni decúbitos con la prótesis provisional. En un segundo tiempo, a los 4 meses, podemos colocar los implantes. ${ }^{37-39}$ is covered with a membrane. ${ }^{25}$ The most important property of autologous bone is its osteogenicity. It also has osteoinductive and osteoconductive properties.

Particulate autologous bone grafts until recently were considered the "gold standard" in the scientific literature. They usually are obtained from intraoral zones using a bone scraper (from the bone adjacent to the bone defect, chin, or maxillomalar buttress) and can form mature bone in 9 months. ${ }^{26}$ A larger volume of regenerated bone and more bone substitution are observed when the particle size is less than $2 \mathrm{~mm}^{3} .^{27}$

Many biomaterials can be used as a particulate graft. Among the biomaterials available is hydroxyapatite, generally of bovine origin. The work of Hallman showed that when hydroxyapatite is mixed with autologous bone in a proportion of 80:20, its osteoconductive properties combine with the osteogenic and osteoinductive properties of autologous bone to produce more rapid and reliable bone regeneration with hardly any resorption. $28-30$ The effect of the autologous bone is not clear, but it seems to reduce the usual healing time of 6 months. ${ }^{31}$ Our clinical experience has shown that the waiting time for implant placement could be reduced reliably to 4 months. Hydroxyapatite also can be mixed with autologous particulate bone time in 1:1 proportion. ${ }^{32}$

\section{Cortical grafts}

Following the criteria published by Collins in 1995,33 there are nine requirements for achieving success with block graft reconstruction:

1. The patient must have realistic and reasonable expectations about what is trying to be achieved.

2. Presurgical study of the case with preparation of models and wax casts of the desired prosthesis.

3. Preparation of a surgical splint.

4. Anatomic reconstruction of the defect.

5. Rigid graft fixation using at least two titanium osteosynthesis screws and making sure that the receptor bone and graft are in intimate contact.

6. Solid fixation of implants in the receptor bone.

7. The graft must be designed so that bone coverage of each face of the implant by at least $1.5 \mathrm{~mm}$ of bone is ensured after optimally positioning implants from a prosthodontic point of view. If this minimum thickness is not achieved, it is likely that graft resorption will expose the implant spiral. This point is especially relevant in grafts in the front tooth zone, where at least $2 \mathrm{~mm}$ of bone coverage on the vestibular face must be achieved.

8. Tension-free flap closure. Exposure to the intraoral medium is the most frequent cause of infection and graft loss.

9. Absence of pressure of the provisional prosthesis on the graft zone.

The cortical grafts most commonly used to restore the front tooth area are of intraoral origin: mandibular ramus and chin. Grafts from the mandibular ramus are associated with less morbidity than grafts from the chin area. ${ }^{34,35}$ After clinical and radiologic examination and confirmation of the need 


\section{Rama ascendente mandibular}

Se aborda mediante una incisión sobre la línea oblicua externa cuidando no lesionar la musculatura y evitando la salida de la bola adiposa de Bichat. Es muy útil la utilización del bisturí piezoeléctrico para el tallado del injerto. Se desprende con escoplo.

\section{Sinfisis mentoniana}

Injerto cortical o corticoesponjoso que obtenemos de una zona limitada lateralmente por los nervios mentonianos y superiormente por los ápices de los dientes. Debe preservarse una distancia de seguridad de 5 milímetros a dichos ápices. Como en la rama ascendente es muy útil el bisturí piezoeléctrico o la fresa de fisura.

\section{Cresta ilíaca}

Permite obtener un injerto cortical o corticoesponjoso de origen endocondral de gran volumen. Es un hueso muy celular y su obtención se realiza con sierra y escoplo. Se acompaña de molestias en la zona dadora en forma de dolor y cojera. La lesión del nervio femorocutáneo está descrita como una de las complicaciones mas frecuentes. La zona más frecuentemente utilizada es la espina ilíaca anterosuperior, que permite trabajar a dos campos y aporta suficiente cantidad de hueso. La espina ilíaca posterosuperior es menos utilizada aunque está publicado que produce una menor morbilidad. 40

\section{Calota craneal}

Injerto cortical de origen membranoso que tiene muy poca reabsorción, su zona dadora no genera molestias y la cicatriz queda oculta por el pelo. Las complicaciones son infrecuentes por lo que es bien tolerado por los pacientes pero cuando se producen pueden ser muy graves (fístulas de líquido cefalorraquídeo, hematomas epidurales, lesiones cerebrales). Puede ser considerado como alternativa al injerto de cresta ilíaca en grandes defectos óseos. ${ }^{41}$ Se obtiene con fresa y escoplo y generalmente se suele utilizar la cortical externa dejando intacta la interna. Al tratarse de un hueso de origen membranoso sufre una menor reabsorción que la cadera. ${ }^{42}$

\section{Protocolo clínico}

\section{Defecto óseo pequeño que no compromete la colocación del implante en posición óptima}

Hay que realizar una valoración previa del biotipo periodontal del paciente ya que, al no comprometer la colocación del implante, un biomaterial maquillará bien el defecto en un biotipo periodontal grueso. En un biotipo fino será necesario injertar tejido conectivo (Esquema 1).

\section{Defecto óseo de una pared que compromete la colocación del implante en posición óptima}

Del mismo modo que en el apartado anterior, ante un biotipo periodontal fino es recomendable realizar un injerto de teji- for a cortical graft, a mucoperiosteal full thickness flap is made to expose the bone defect. The graft then is obtained, often using a piezoelectric scalpel to cut and adapt the cortical graft. The graft is attached with osteosynthesis screws and empty spaces are filled with a mixture of autologous bone obtained by scraping and hydroxyapatite or demineralized bone matrix. All the graft material is covered with an absorbable collagen membrane and sutured without tension using 5-0 and 6-0 monofilament. ${ }^{36}$ Suture tension can be avoided by performing periosteotomy on the receptor bed of the graft prior to obtaining the graft, which ensures that bleeding secondary to graft harvesting occurs at the beginning of the intervention and not at the end. The cortical graft must be perfectly adapted and free of edges that can cause suture dehiscence or rubbing with the provisional prosthesis. The implant is placed in a second intervention at 4 months. ${ }^{37-39}$

\section{Mandibular ramus}

This area is approached by means of an incision on the external oblique line, taking care not to injure the musculature of the buccal fat pad. It Is useful to carve the graft with a piezoelectric scalpel. The graft is raised with a chisel.

\section{Mental symphysis}

Cortical or cortico-cancellous graft is obtained from a zone limited laterally by the mental nerves and superiorly by the dental apices. A safety margin of $5 \mathrm{~mm}$ from these apices must be preserved. As in the mandibular ramus, a piezoelectric scalpel or fissure bur is useful.

Iliac crest

A large-volume cortical or cortico-cancellous bone graft of endochondral origin can be obtained from the hip. This bone is highly cellular and a saw and chisel are used for harvesting. Bone harvesting can cause discomfort in the donor area resulting in pain and limping. Injury to the femoral cutaneous nerve is one of the most frequent complications. The zone most often used is the anterosuperior iliac spine, which enables work on two fields and supplies sufficient bone. The posterosuperior iliac crest is used less but has been reported to produce less morbidity. 40

Skull

A cortical graft of membranous origin is obtained that results in little resorption. The donor zone does not cause discomfort and the scar is hidden by the hair. Complications are uncommon, so the graft is well tolerated by patients. How- 
do conectivo profiláctico. En estos casos la mejor opción reconstructiva es el injerto de hueso autólogo obtenido por raspador mezclado 1:1 con biomaterial (hidroxiapatita) y cubierto por una membrana de colágeno reabsorbible. El injerto cortical o la membrana de e-PTFE son también opciones válidas pero nos parece que el injerto autólogo obtenido por raspador es predecible, menos agresivo que el injerto cortical y más seguro que la membrana de e-PTFE. En los tres casos al cuarto mes deberemos obtener hueso maduro sin tejido inflamatorio (Esquema 2).

\section{Defecto óseo de dos o tres paredes}

Ante un biotipo periodontal fino es recomendable realizar un injerto de tejido conectivo profiláctico teniendo en cuenta que si se trata de un gran defecto puede realizarse un colgajo de tejido conectivo pediculado. Al tratarse de defectos óseos de dos o tres paredes y no ser autorretentivos la mejor opción reconstructiva es el injerto autólogo cortical. Para defectos menores de 3 centímetros la rama ascendente y el mentón son las fuentes de elección, siendo la rama ascendente nuestra primera elección. En nuestra opinión para defectos mayores de 3 centímetros hay que acudir a fuentes extraorales como la calota craneal o la cresta ilíaca. Se rellenan los espacios muertos con injerto de hueso autólogo particulado mezclado 1:1 con biomaterial (hidroxiapatita). El injerto cortical debe estar fija-

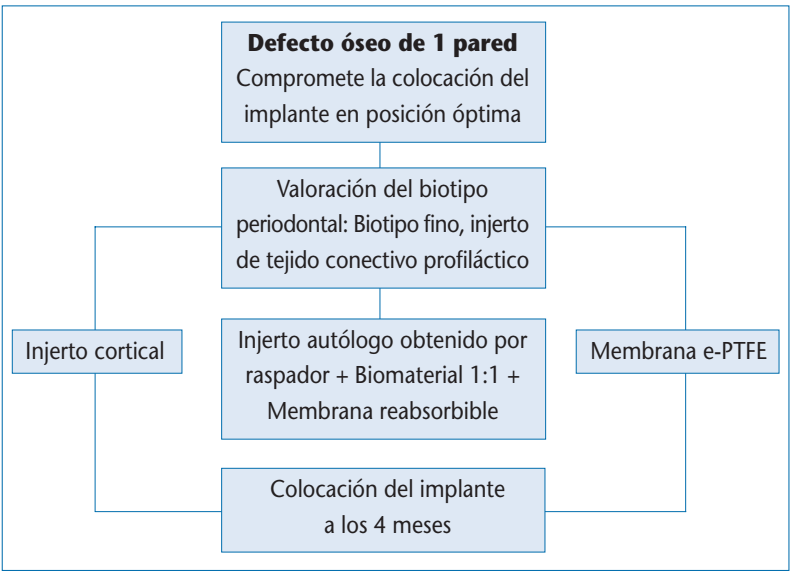

Esquema 2.

Scheme 2.

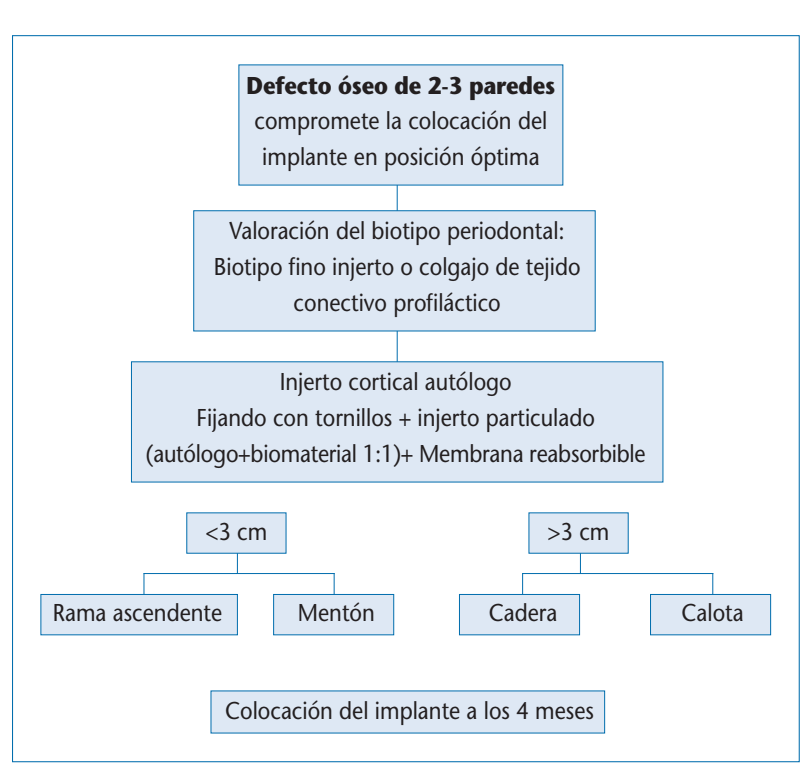

Esquema 3.

Scheme 3.

\section{Clinical protocol}

Small bone defect that does not compromise optimal implant placement

The patient's periodontal biotype has to be assessed previously because a biomaterial does not jeopardize implant placement and will provide good cosmetic coverage of the defect in patients with a thick periodontal biotype. In patients with a thin periodontal biotype, a connective tissue graft is necessary (Scheme 1).

Parietal bone defect that compromises optimal implant placement As in the previous section, a prophylactic connective tissue do por dos tornillos de osteosíntesis. Todo el material de injerto estará protegido por una membrana de colágeno. Los implantes se colocarán a los 4 meses (Esquema 3).

\section{Casos clínicos}

Para terminar de ilustrar nuestro protocolo vamos a mostrar tres casos clínicos de colocación de implantes en el sector estético con defectos óseos de diferente entidad tratados cada uno en función de la magnitud del defecto óseo y las características del biotipo periodontal del paciente.

\section{Caso clínico 1}

Paciente con lesión crónica en incisivo lateral izquierdo que obliga a exodoncia y ROG con membrana no reabsorbible. Biotipo periodontal fino y línea de sonrisa alta como factores de riesgo (Fig. 8 a 19). graft is recommended in the case of thin periodontal biotype. In these cases, the best reconstructive option is autologous bone graft obtained by scraping and mixed 1:1 with biomaterial (hydroxyapatite). The graft area is covered with an absorbable collagen membrane. A cortical graft or e-PTFE membrane also is a valid option, but autologous graft material collected by scraping is predictable, less aggressive than cortical grafts and safer than the e-PTFE membrane. In all three cases, mature bone without inflammatory tissue should be obtained by the fourth month (Scheme 2).

Two or three-wall bone defect

In patients with a thin periodontal biotype, a prophylactic connective tissue graft is recommended because a pediculated connective tissue graft can be made if the defect is large. In the case of two or three-wall bone defects, the best reconstructive option is cortical autologous graft because the grafts 


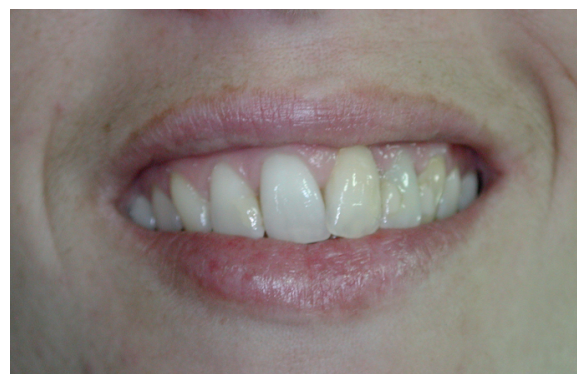

Figuras 8 y 9. Caso 1. Aspecto de la paciente previo a la exodoncia. Nótese la fístula vestibular del 22 que nos hará sospechar la afectación ósea de la tabla vestibular.

Figures 8 and 9. Case 1. Appearance of the patient prior to tooth extraction. Note the vestibular fistula of piece 22, which suggests bone affectation of the vestibular table.

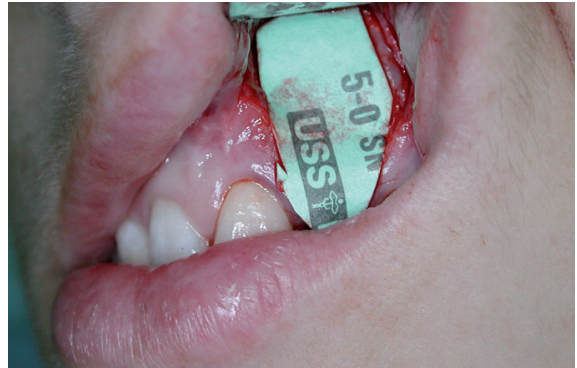

Figura 11. Utilización del sobre de la sutura como molde para preparar la membrana. Figure 11. Use of the suture envelope as a mold for preparing the membrane.
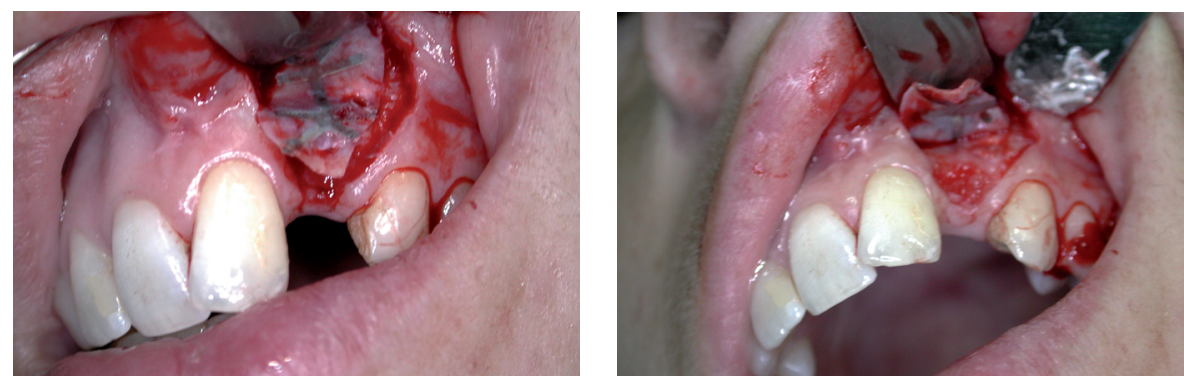

Figuras 14 y 15. Retirada de la membrana al cuarto mes comprobando la existencia de hueso apto para la colocación del implante utilizando una incisión que preserva las papilas.

Figures 14 and 15. Removal of the membrane at four months. Verification of the presence of bone suitable for implant placement using an incision that preserves the gingival papillae.

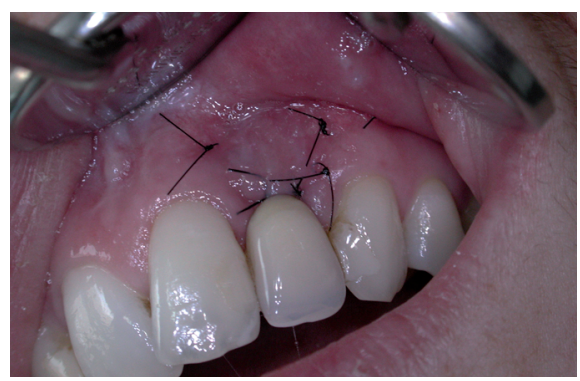

Figura 17. Sutura monofilamento $5 / 0$. Figure 17. 5-0 monofilament suture.
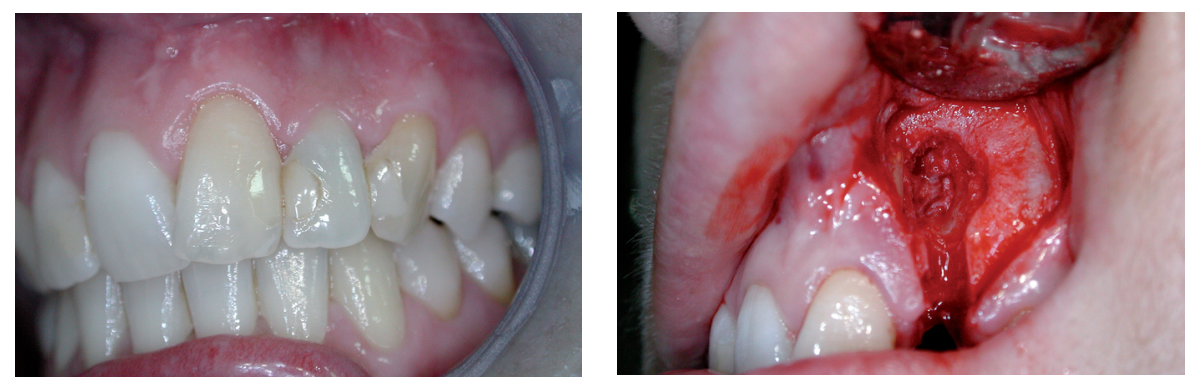

Figura 10. Defecto óseo de tabla vestibular tras la exodoncia de 22.

Figure 10. Bone defect of the vestibular table after extraction of \#22.

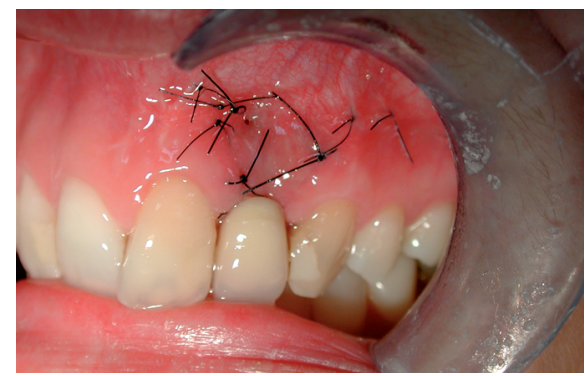

Figura 13. Sutura sin tensión del colgajo de espesor total con monofilamento 5/0.

Figure 13. Tension-free suture of a full-thickness flap with 5-0 monofilament.

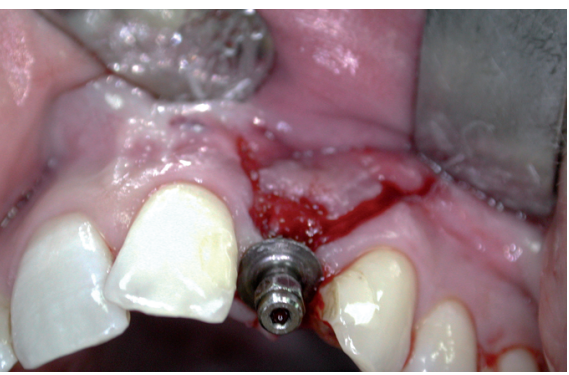

Figura 16. Colocación del implante en posición 22 al cuarto mes tras la retirada de la membrana. Implante de diámetro 3,25 milímetros. Figure 16. Placement of implant in position 22 four months after membrane removal. Implant diameter $3.25 \mathrm{~mm}$.

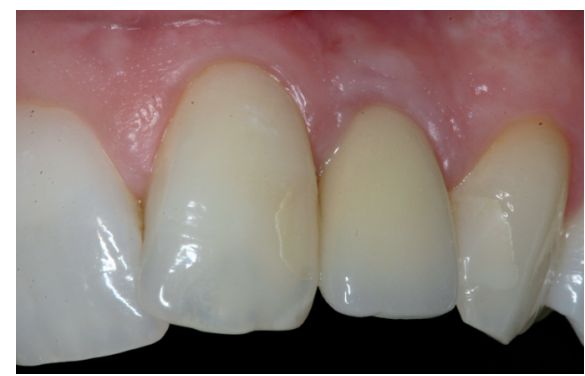

Figuras 18 y 19. Prótesis metal cerámica sobre implante con buen control estético de la anatomía dental, margen gingival y papilas interdentales (Prostodoncista Dr. A. Ortega, Técnico de laboratorio J. Campins)

Figures 18 and 19. Implant-mounted ceramic and metal prosthesis with a good aesthetic outcome in terms of dental anatomy, gum margin, and interdental papillae (Prosthodontist Dr A. Ortega, Laboratory Technician J. Campins). 


\section{Caso clínico 2}

Paciente remitido para exodoncia de 23 con fractura radicular y posible fractura de 22, ambos con endodoncias de larga evolución. Ante la posible afectación de una pared en el momento de la exodoncia se plantea regeneración ósea con injerto particulado (Figs. 2037).

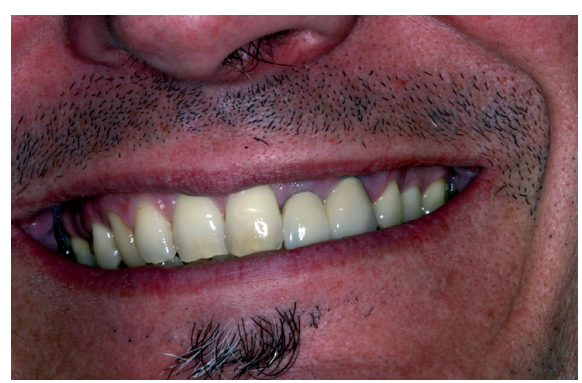

Figura 20. Caso 2. Biotipo periodontal medio con línea de sonrisa mostrando el margen gingival de los dientes afectos.

Figure 20. Case 2. Intermediate periodontal biotype with a smile line showing the gingival margin of the teeth affected.

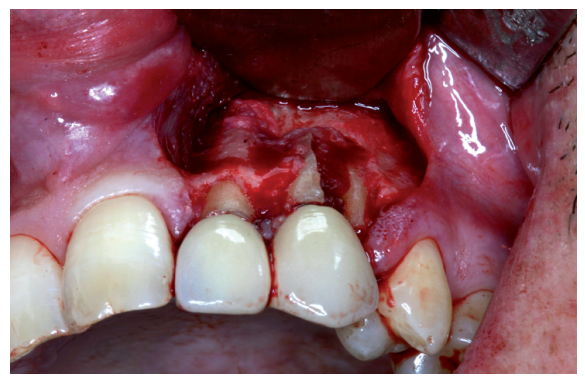

Figura 22. Imagen clínica donde se comprueba la fractura del 23 y la indemnidad del 22 . La exodoncia del 22 supondría la pérdida de una masa ósea crítica para el resultado estético del mismo.

Figure 22. Clinical image confirming fracture of 23 and an intact 22. Removal of 22 would result in the loss of bone mass critical to achieving an acceptable aesthetic result.

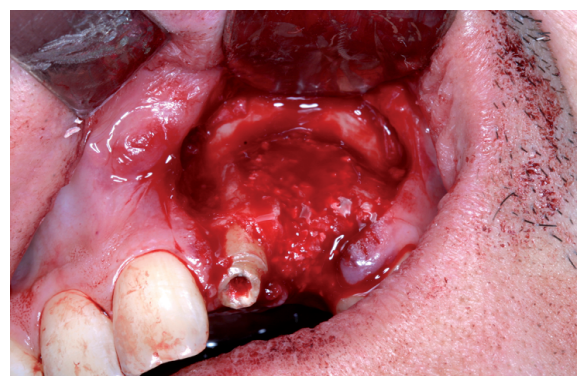

Figura 24. Injerto óseo particulado compuesto (hueso autólogo obtenido por raspador mezclado con hidroxiapatita).

Figure 24. Compound particulate bone graft (autologous bone obtained by scraping mixed with hydroxyapatite).

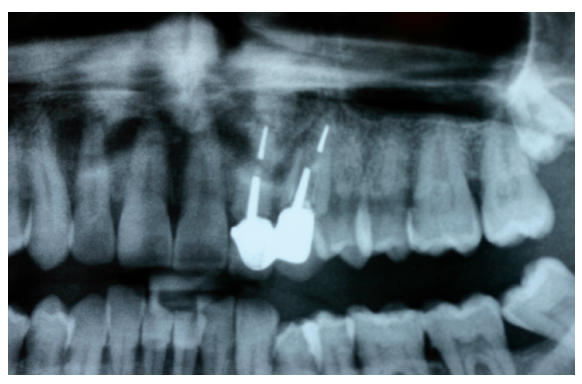

Figura 21. Ortopantomografía en la que se aprecia una fractura del 23 y dudosa fractura del 22.

Figure 21. Orthopantomography in which fracture of 23 and a possible fracture of 22 is visible.

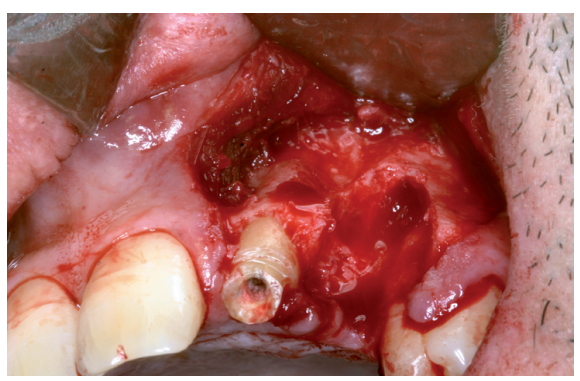

Figura 23. Defecto óseo de una pared postextracción que compromete la colocación del implante en posición óptima.

Figure 23. Postextraction bone defect in a wall that jeopardizes optimal implant placement.

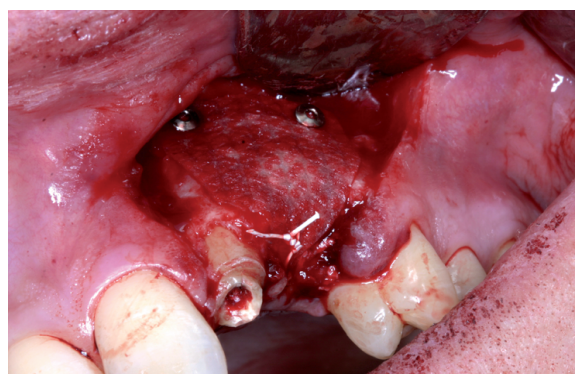

Figura 25. Cobertura del injerto óseo con una membrana reabsorbible fijada con chinchetas de RTG en la parte mas apical y suturada con un punto reabsorbible en la parte crestal.

Figure 25. Coverage of the bone graft with an absorbable membrane attached with GBR pins apically and sutured with absorbable suture to the crest.

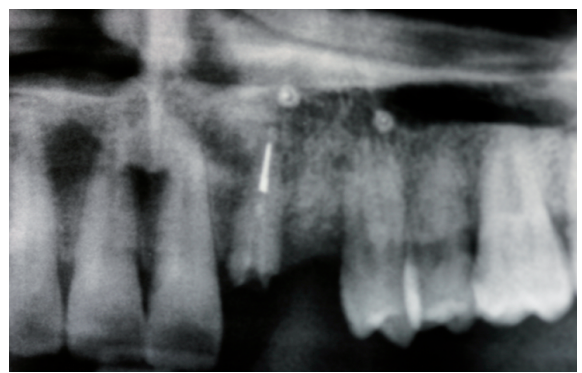

Figura 26. Imagen radiográfica de la regeneración ósea al cuarto mes.

Figure 26. Radiographic image of bone regeneration at four months. 

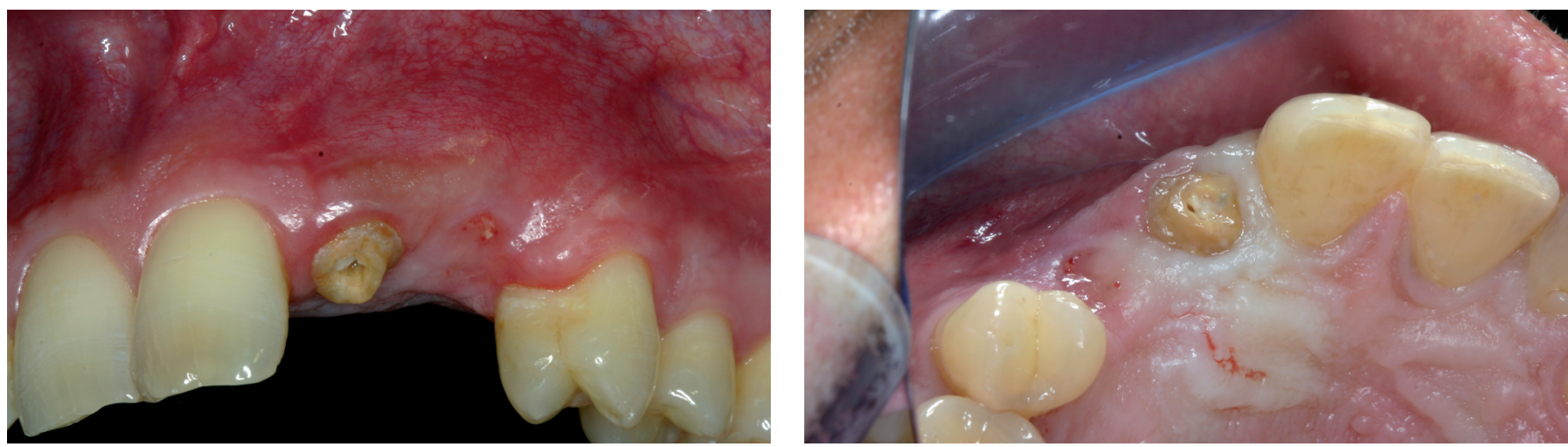

Figuras 27 y 28. Aspecto de los tejidos al cuarto mes de la regeneración ósea. Se ha conseguido un aumento horizontal con un nivel óptimo de encía queratinizada y apenas se observan cicatrices.

Figures 27 and 28. Appearance of tissues at four months of bone regeneration. A horizontal increase with an optimal level of keratinized gum has been achieved. Little scarring is visible.
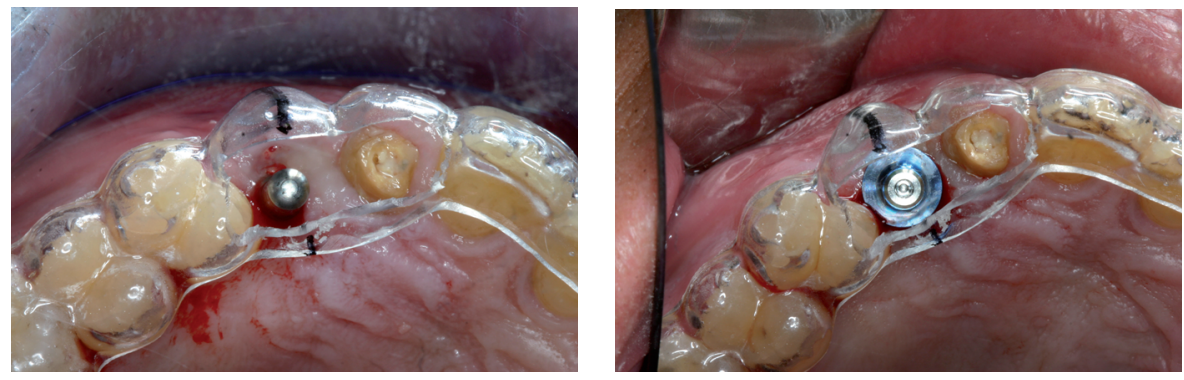

Figura 29 y 30. Imágenes de la colocación del implante al cuarto mes de la regeneración ósea de forma mínimamente invasiva gracias al buen manejo de los tejidos blandos.

Figure 29 and 30. Images of implant placement at four months of minimally invasive bone regeneration thanks to proper soft tissue management.
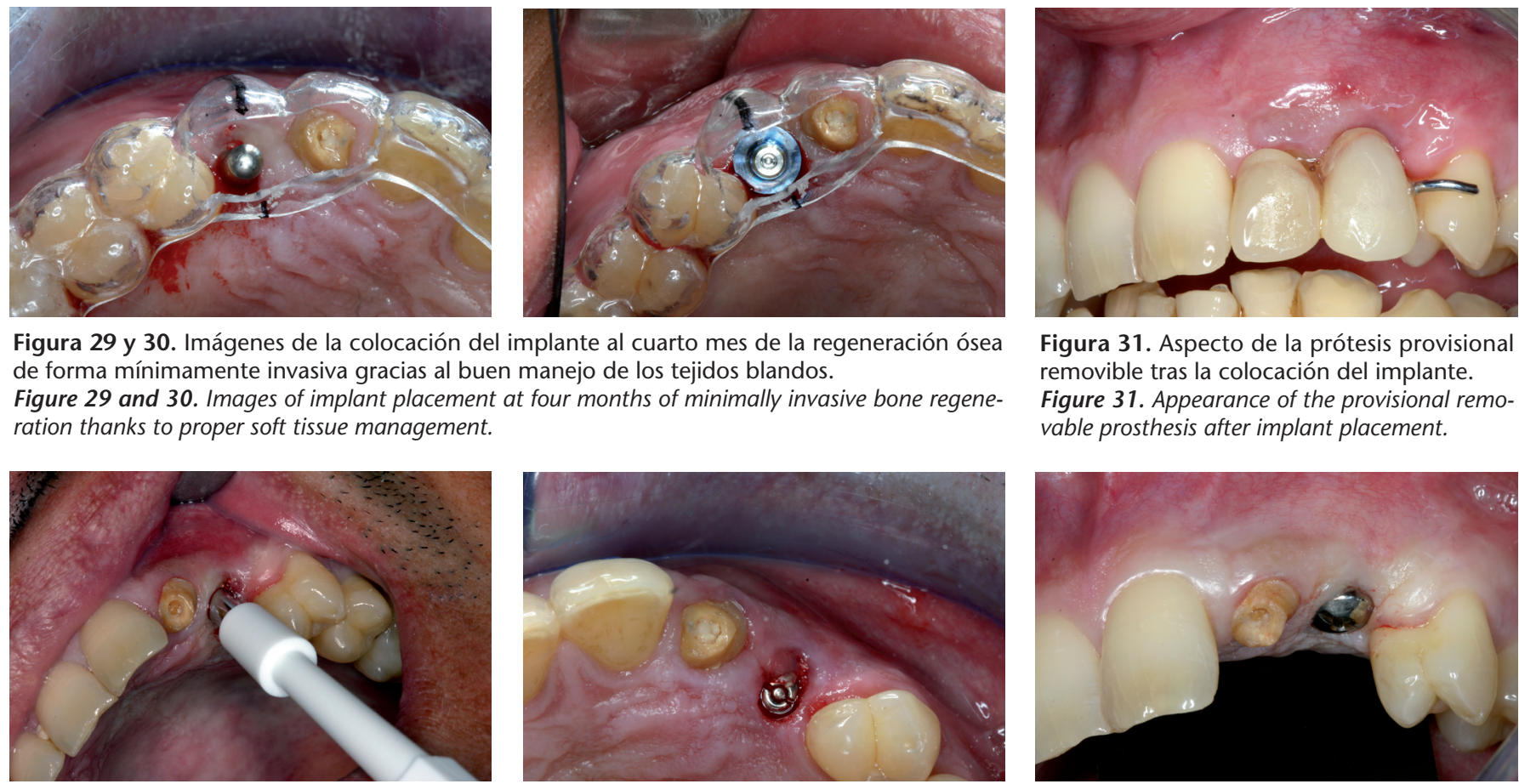

Figura 31. Aspecto de la prótesis provisional removible tras la colocación del implante.

Figure 31. Appearance of the provisional removable prosthesis after implant placement.

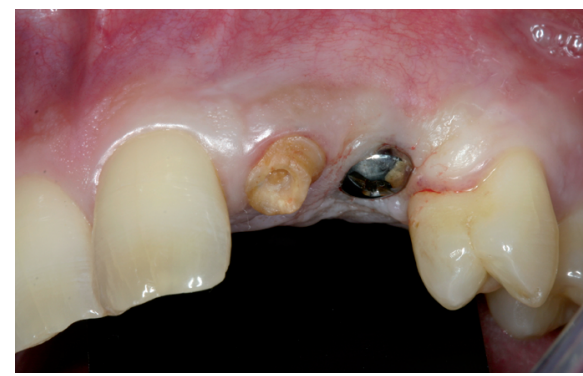

Figuras 32, 33 y 34. Segunda fase quirúrgica realizada de modo mínimamente invasivo. Conexión de pilar de cicatrización de 4 milímetros. Figures 32, 33 and 34. Second surgical phase done in a minimally invasive way. Connection of 4-mm healing post.
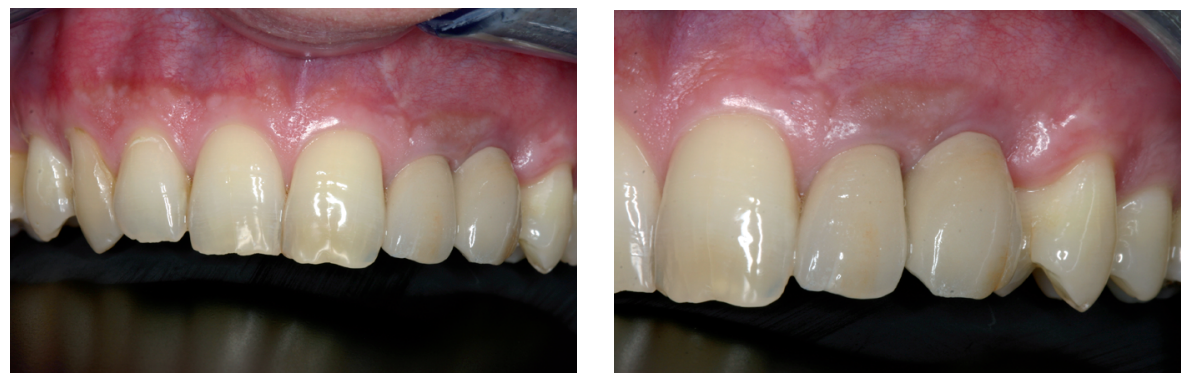

Figuras 35 y 36. Imagen de la restauración definitiva sobre 22 y 23. (Prostodoncista: Dr. Bartolomé Vich, Técnico de laboratorio: Alberto Tomás).

Figures 35 and 36. Image of the definitive restoration of 22 and 23 (Prosthodontist: Dr. Dr Bartholomew Vich, Laboratory Technician: Alberto Tomás).

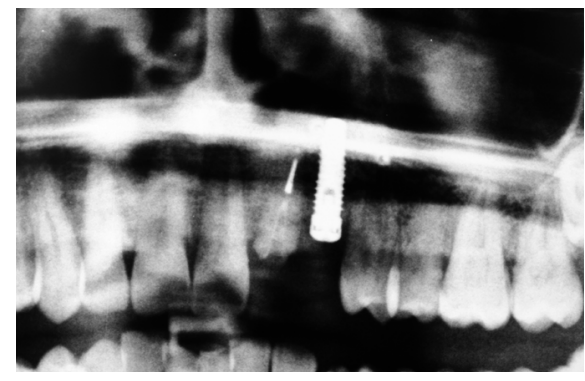

Figura 37. Ortopantomografía de control del caso respetando la distancia mínima entre implantes.

Figure 37. Follow-up orthopantomography of the case showing conservation of the minimum distance between implants. 


\section{Caso clínico 3}

Paciente de 24 años con antecedente traumático que provocó la perdida del diente 21 a los 16 años. Consulta para posibilidad de sustituir su actual prótesis acrílica removible por una prótesis implanto-soportada (Figs. 38 a 79).

\section{Clinical case 3}

A 24-year-old patient had suffered trauma that caused the loss of 21 when 16 years old. The patient consulted about replacing a removable acrylic prosthesis with an implantsupported prosthesis (Figs. 38 a 79).
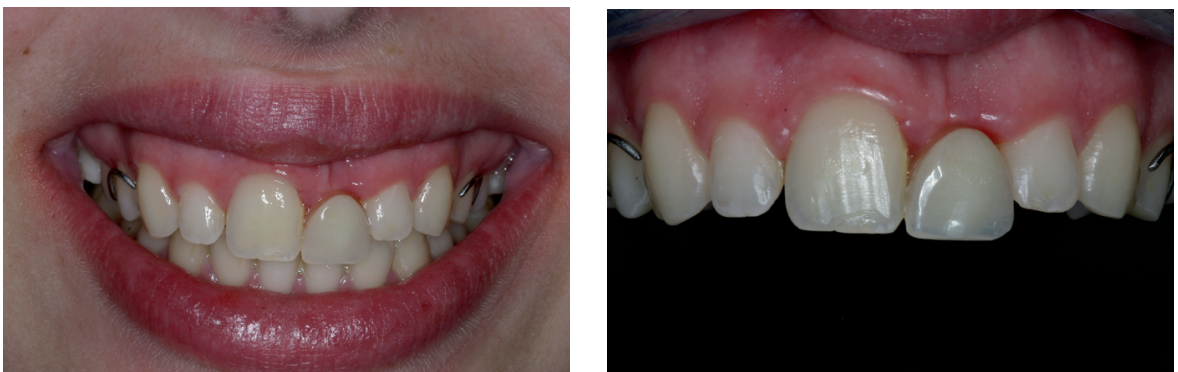

Figuras 38 y 39. Imagen de la paciente mostrando un biotipo periodontal grueso, una línea de sonrisa alta y la prótesis acrílica removible.

Figures 38 and 39. Image of patient showing a thick periodontal biotype, high smile line, and removable acrylic prosthesis.

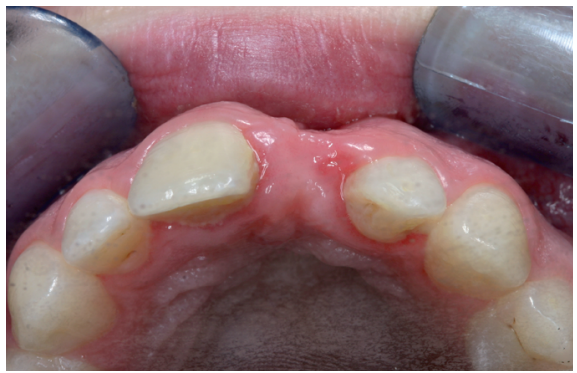

Figura 41. La vista oclusal permite identificar un defecto vestíbulo-palatal que puede comprometer la colocación del implante en posición óptima.

Figure 41. The occlusal view allows identification of a vestibulo-palatal defect that can jeopardize optimal implant placement.

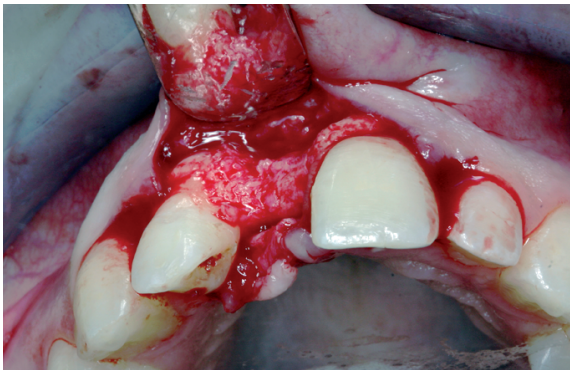

Figura 44. Identificación clínica del defecto ántero-posterior que compromete la colocación óptima del implante en tres dimensiones. Figure 44. Clinical identification of the anteroposterior defect that compromised optimal implant placement in three dimensions.
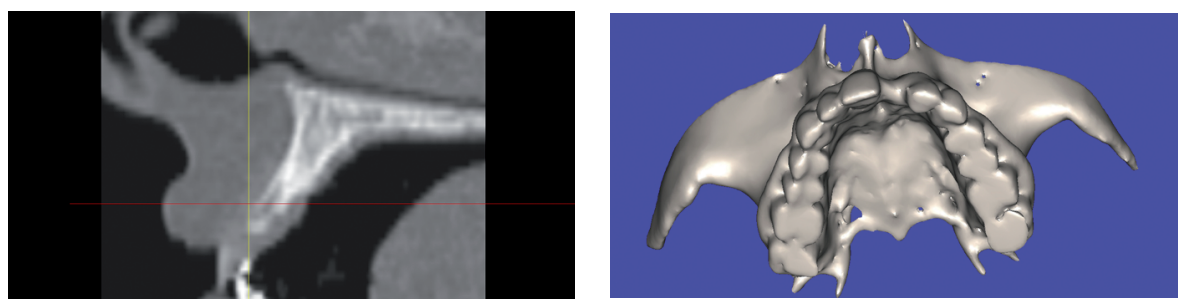

Figuras 42 y 43 . Se realiza TC y procesado 3D para completar el estudio del caso y se comprueba el defecto vestíbulo-palatal en posición 21. La tabla ósea vestibular no va a tener los 2 milímetros de hueso necesarios para proteger una posible retracción gingival. Se decide que en este caso se precisa un injerto cortical que se obtendrá de la rama mandibular ascendente.

Figures 42 and 43. CT scan and three-dimensional processing to complete the case study confirmed the vestibulo-palatal defect in 21. The vestibular bone table did not have the $2 \mathrm{~mm}$ of bone necessary to protect against possible gum retraction. The decision was made to perform a cortical graft with bone from the mandibular ramus.
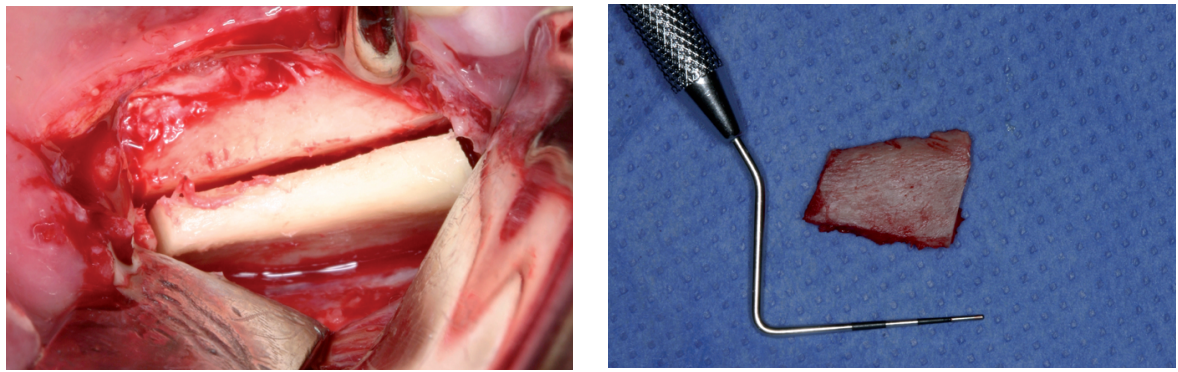

Figuras 45 y 46 . Obtención de injerto cortical de rama ascendente mandibular mediante bisturí piezoeléctrico.

Figures 45 and 46. The cortical graft was obtained from the mandibular ramus using a piezoelectric scalpel. 


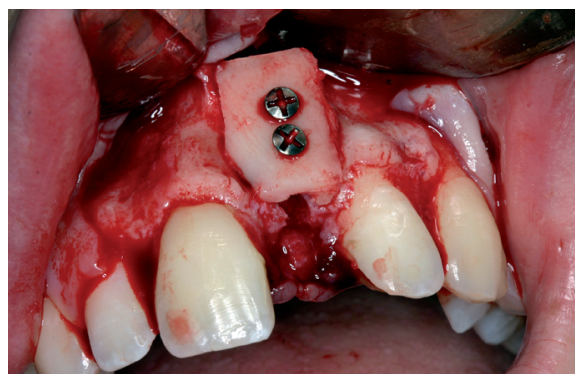

Figura 47. Estabilización del injerto con dos tornillos de osteosíntesis.

Figure 47. Graft stabilization with two osteosynthesis screws.
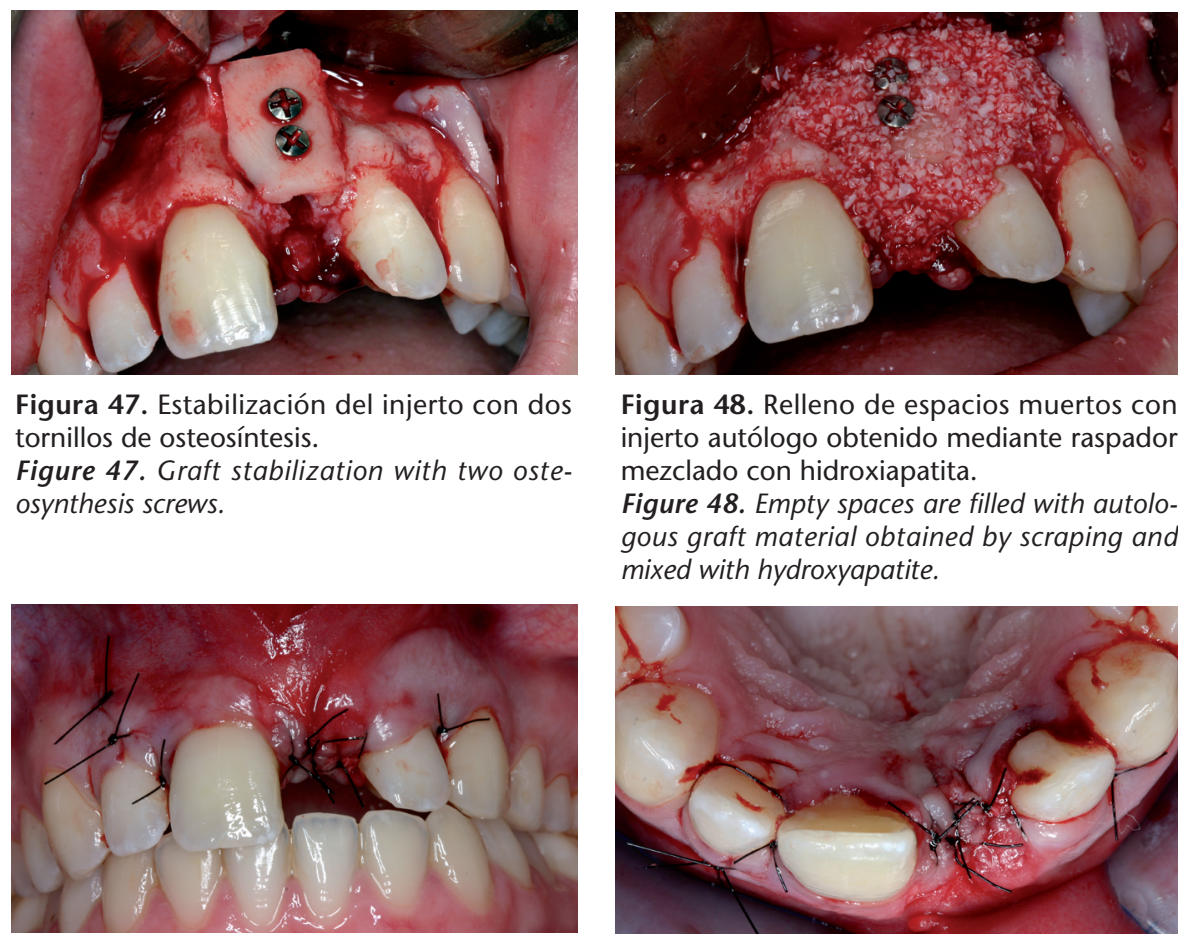

Figura 48. Relleno de espacios muertos con injerto autólogo obtenido mediante raspador mezclado con hidroxiapatita.

Figure 48. Empty spaces are filled with autologous graft material obtained by scraping and mixed with hydroxyapatite.

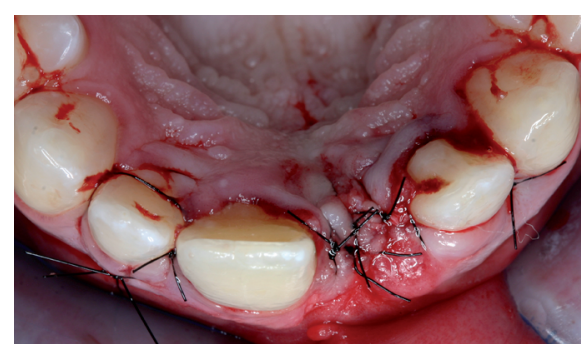

Figuras 50 y 51 . Sutura sin tensión mediante monofilamento $5 / 0$ y $6 / 0$. Se ha realizado una periostiotomía en las primeras fases de la cirugía, para evitar el sangrado en el momento de la sutura.

Figures 50 and 51. Tension-free suture with 5-0 and 6-0 monofilament. Periosteotomy was performed in the first stage of surgery to avoid bleeding during suturing. Follow-up orthopantomography at four months showing good appearance of the regenerated zone.

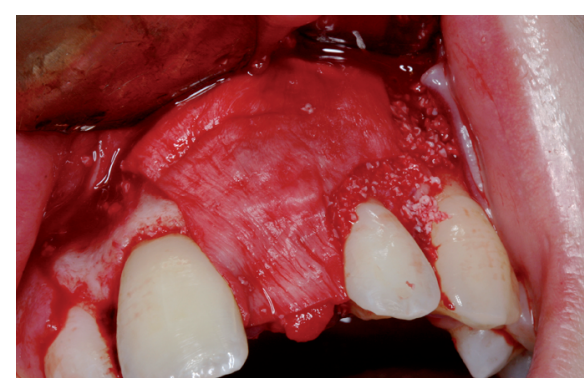

Figura 49. Cobertura del mismo con una membrana de colágeno (reabsorbible).

Figure 49. Coverage of the graft with collagen membrane (absorbable).

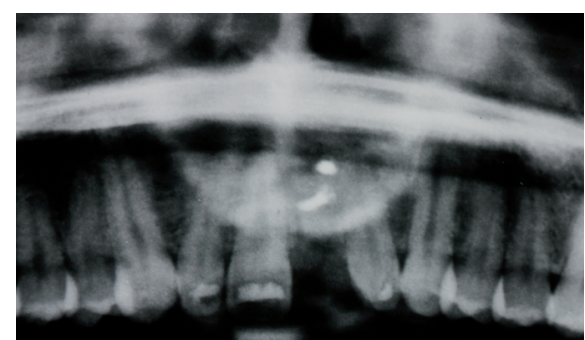

Figura 52. Ortopantomografía de control a los cuatro meses con buen aspecto en la zona regenerada.

Figure 52. Follow-up orthopantomography at four months showing good appearance of the regenerated zone.
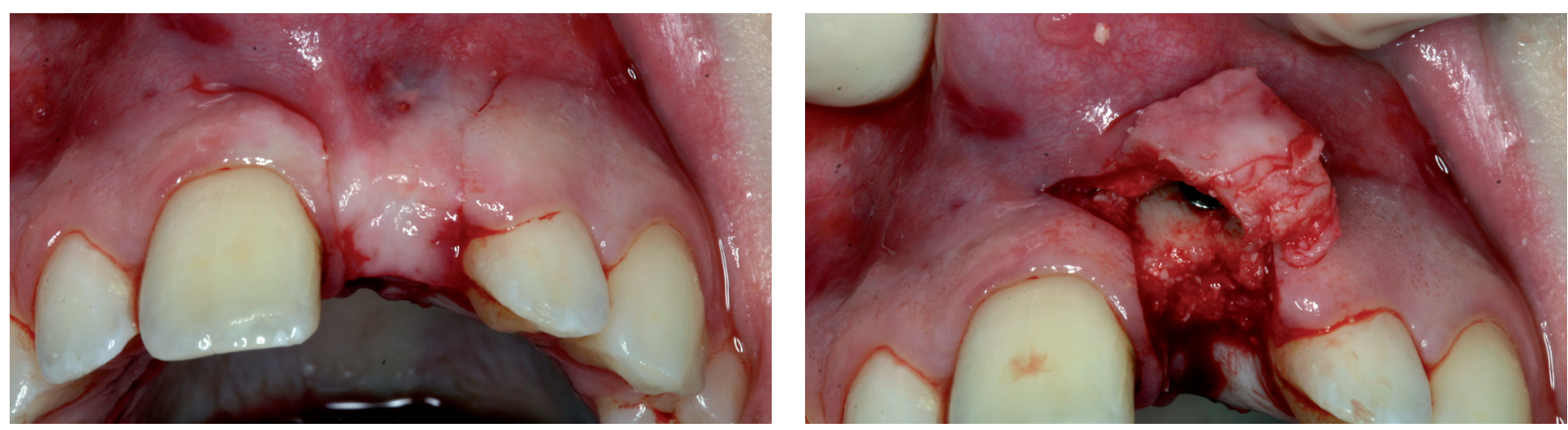

Figuras 53 y 54. Reentrada a los cuatro meses mediante una incisión trapezoidal preservando las papilas y con un colgajo pediculado de tejido conectivo (Roll technique).

Figures 53 and 54. Re-entry at four months using a trapezoidal incision to preserve gingival papillae and a pediculated connective tissue flap (Roll technique).
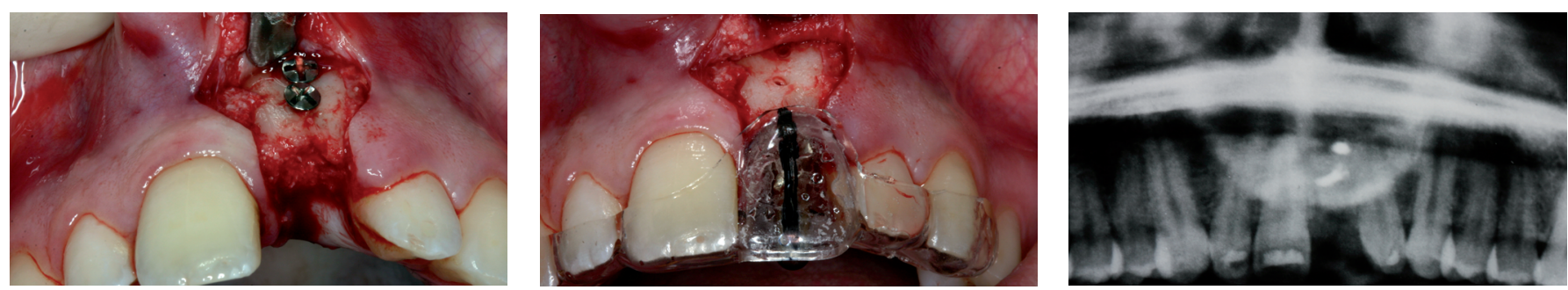

Figuras 55, 56 y 57. Excelente aspecto del injerto al cuarto mes. Momento que aprovechamos para la colocación del implante de 4 x 13 milímetros) y la retirada del material de osteosíntesis.

Figures 55, 56 and 57. Excellent graft appearance at four months. At this time the 4 ? $13 \mathrm{~mm}$ implant was placed and the osteosynthesis material was removed. 

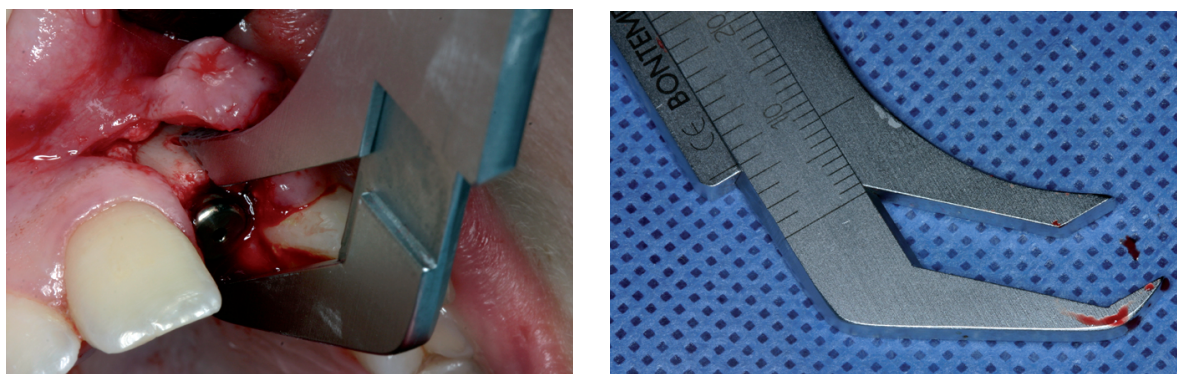

Figura 58 y 59. Hemos obtenido una anchura de 9 milímetros que asegura la estabilidad del implante a largo plazo.

Figure 58 and 59. A 9-mm width was obtained, which ensures long-term implant stability.

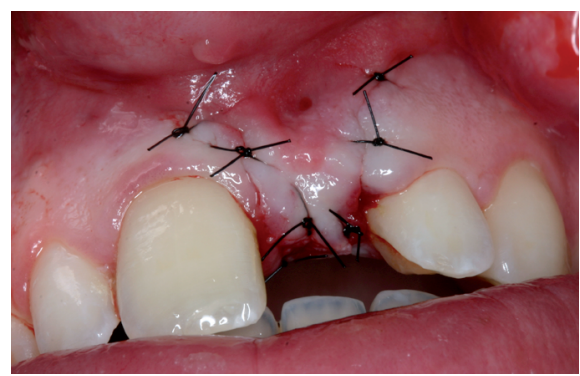

Figura 60. Sutura de la incisión adaptando el injerto pediculado de tejido conectivo con monofilamento $5 / 0$ y $6 / 0$.

Figure 60. Suture of the incision with 5-0 and 60 monofilament by adapting the pediculated connective tissue graft.
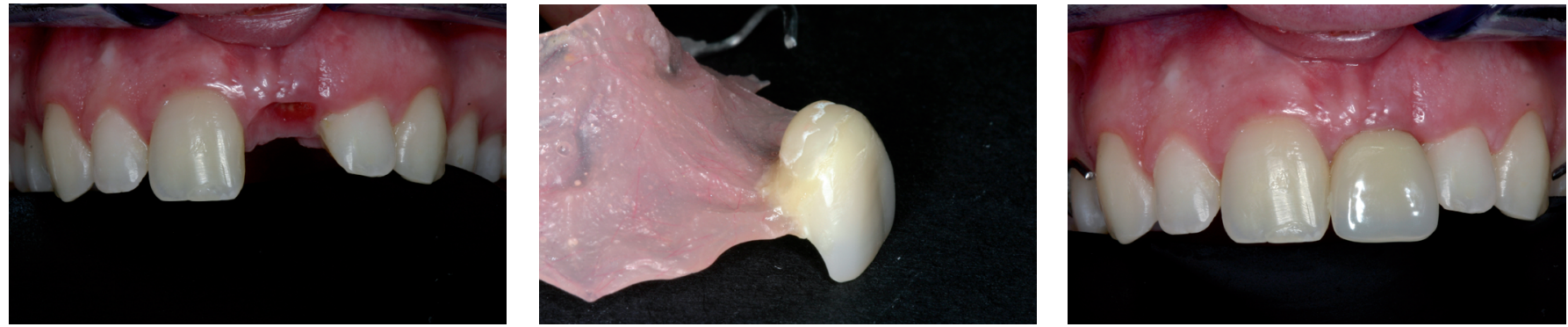

Figura 61, 62 y 63. Durante el proceso de osteointegración, la paciente lleva su prótesis removible que va siendo modificada con composite para ir modelando el perfil de emergencia.

Figure 61, 62 and 63. During the osseointegration process, the patient wore a removable prosthesis that was modified with composite to model the profile of the emergent tooth.
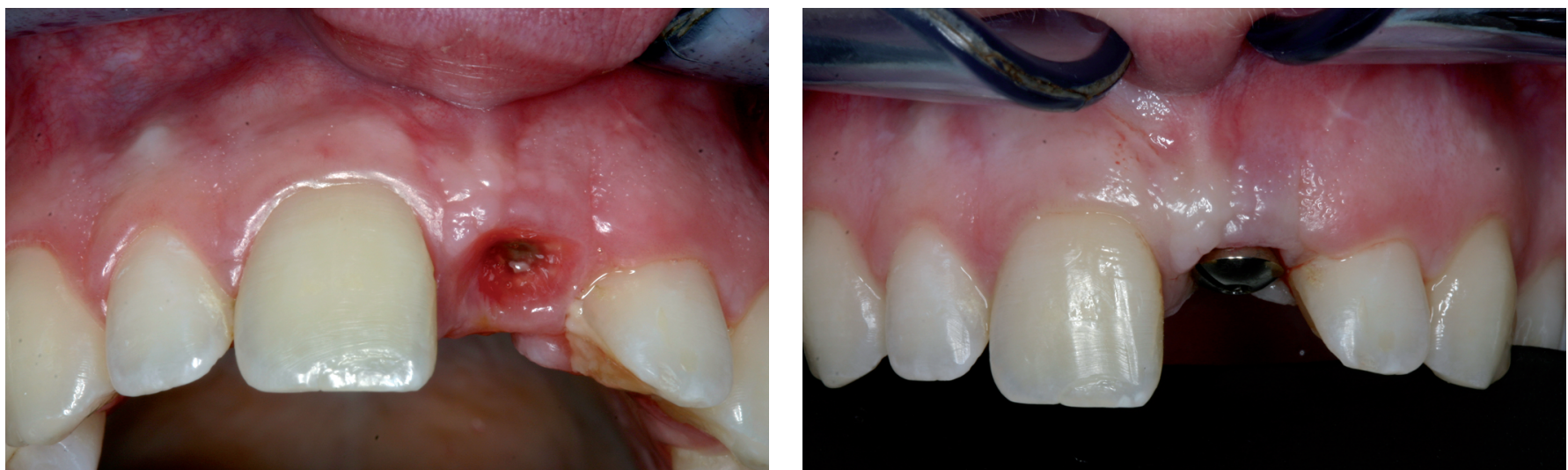

Figuras 64 y 65 . Segunda fase quirúrgica con conexión del pilar de cicatrización de 4 milímetros de modo mínimamente invasivo. Figures 64 and 65 . Second surgical phase with connection of the 4-mm healing post in a minimally invasive way.
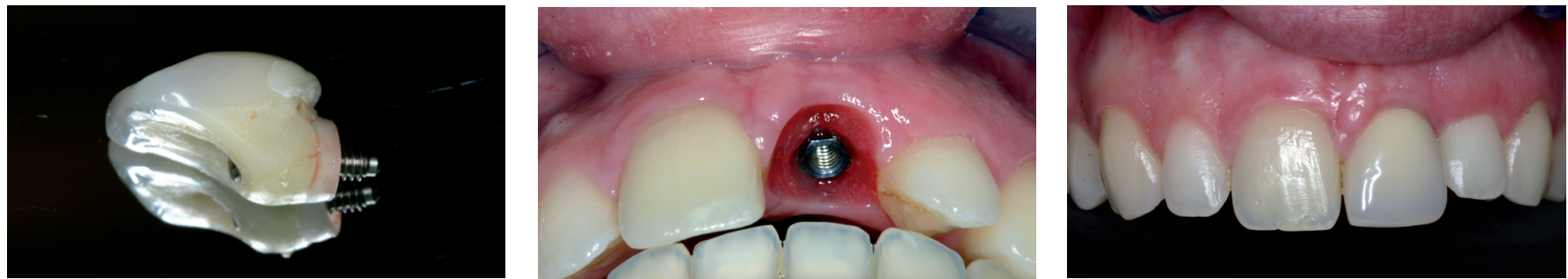

Figuras 66, 67 y 68. Provisional atornillado sobre el implante para ir modelando el perfil de emergencia. Figures 66, 67 and 68. Provisional screw-on implant for modeling the emergent tooth prosthesis. 

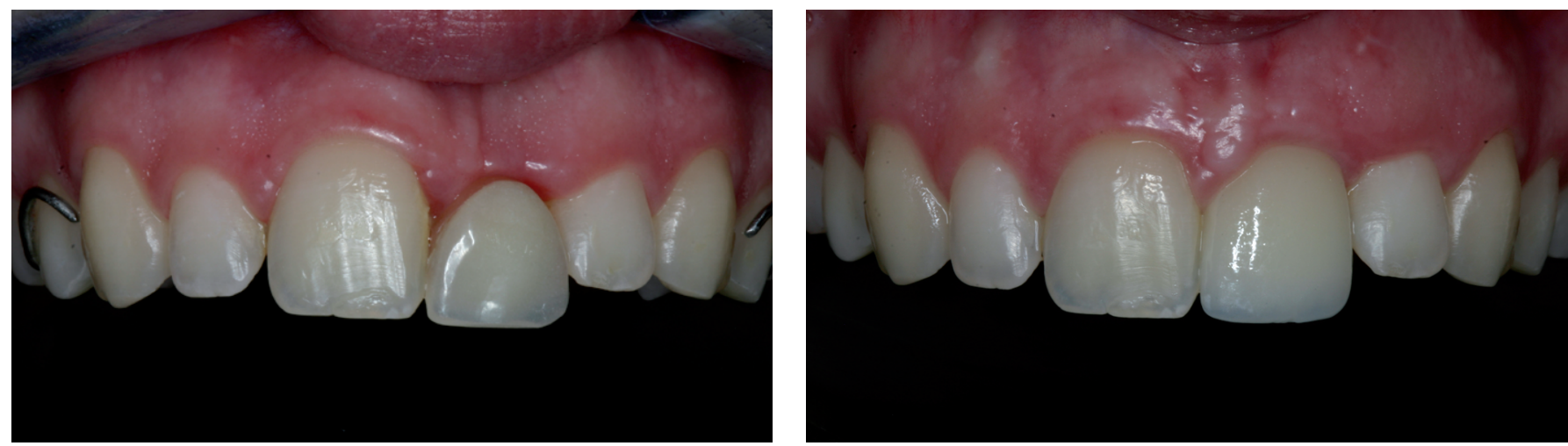

Figura 69 a. Imagen preoperatoria. b. Restauración definitiva sobre pilar de circonio (Prostodoncista: Dr. Ángel Ortega Zaforteza, Técnico de laboratorio: Jaime Campins).

Figure 69 a. Pre-operative image. b. Definitive restoration on a zirconium post (Prosthodontist: Dr. Angel Ortega Zaforteza, Laboratory Technician: Jaime Campins).

\section{Bibliografía}

1. Tjan AH, Miller GD, The JG. Some esthetic factors in a smile. J Prosthet Dent 1984;51: 24-8.

2. Olsson $\mathrm{M}$, Lindhe J. Periodontal characteristics in individuals with varying form of the upper central incissors. / Clin Periodontal 1991;18:7882.

3. Salama H, Salama MA, Garber D, y cols. The interproximal height of bone: a guidepost to predictable aesthetic strategies and soft tissue contours in anterior tooth replacement. Pract Periodontics Aesthet Dent 1998; 10:1131-41.

4. Sclar A. Soft tissue and esthetic considerations in implant therapy. Quintessence Books Publishing co.

5. Saadoun AP, Le Gall M, Touati B. Current trends in implantology: Part II- Treatment, Planning, Aesthetic Considerations and Tisue Regeneration. Pract Proced Aesthet Dent 2004; 16:707-14.

6. Tarnow DP, Cho SC, Wallace SS. The effect of inter-implant distance on the heigth of inter-implant bone cresta. J Periodontol 2000;71:546-9.

7. Tarnow DP, Magner AW, Fletcher P. The effect of the distance from the contact point to the crest of bone on the presence or absence of the interproximal dental papilla. J Periodontol 1992;63:995-6.

8. Tarnow DP, Elian N, Fletcher P, Froum S, Magner A, Cho SC, y cols. Vertical distance from the crest of bone to the height of the interproximal papilla between adjacent implants. J Periodontol 2003;74: $1785-8$.

9. Elian N, Ehrlich B, Jalbout ZN, Classi AJ, Cho SC, Kamer AR, Froum $\mathrm{S}$, Tarnow DP. Advanced Concepts in Implant Dentistry: Creating the "Aesthetic Site Foundation". Dent Clin N Am 2007;51:547-63.

10. Buser D, Martin W, Belser U. Optimizing esthetics for implant restorations in the anterior maxilla: anatomic and surgical considerations. Int J Oral Maxillofac Implants 2004;19Suppl:43-61.

11. Simion $M$, Trisi $P$, Piatelli A. Vertical ridge augmentation using a membrane technique associated with osseointegrated implants. Int J Periodontics Restorative Dent 1994;14:496-511.

12. Simion M, Baldoni M, Rossi P, Zaffe D. A comparative study of the effectiveness of e-PTFE membranes with and without early exposure during the healing period. Int I Periodontics Restorative Dent 1994;14: $166-80$.

13. Simion M, Jovanovic SA, Tinti C, Benfenati SP.Long-term evaluation of osseointegrated implants inserted at the time or after vertical ridge augmentation. A retrospective study on 123 implants with 1-5 year follow-up. Clin Oral Implant Res 2001;12:35-45.

14. Zitzmann NU, Naef R, Schärer P. Resorbable versus non resorbable membranes in combination with Bio-Oss for guided bone regeneration. Int J Oral Maxillofac Implants 1997; 12:844-52.

15. Proussaefs $P$, Lozada J. The use of resorbable collagen membrane in conjunction with autogenous bone graft and inorganic bovine mineral for buccal/labial alveolar ridge augmentation: a pilot study. J Prosthet Dent 2003 Dec;90: 530-8.

16. Salata LZ, Rasmusson L, Kanhberg KE. Effects of a mechanical barrier on the integration of cortical onlay bone grafts placed simultaneously with endosseus implant. Clin Implant Dent Relat Res 2002;4:60-8.

17. Von Arx T, Cochran DL, Hermann JS, Schenk RK, Buser D. Lateral ridge augmentation using different bone fillers and barrier membrane application. A histologic and histomorphometric pilot study in the canine mandible. Clin Oral Implants Res 2001;12:260-9.

18. Hernández-Alfaro F, Torradeflot MM, Marti C. Prevalence and management of Schneiderian membrane perforations during sinus-lift procedures. Clin Oral Implants Res 2008;19:91-8. Epub 2007 Oct 23.

19. Simion M, Scarano A, Gionso L, Piatelli A. Guided bone regeneration using resorbable and nonresorbable membranes: a comparative histologic study in humans. Int J Oral Maxillofac Implants 1996;11: 735-42.

20. Carpio L, Loza J, Lynch S, Genco R. Guided bone regeneration around endosseous implants with anorganic bovine bone mineral. A randomized controlled trial comparing bioabsorbable versus non-resorbable barriers. J Periodontol 2000;71:1743-9.

21. Friedmann A, Srietzel FP, Maretzki B, Pitaru S, Bernimoulin JP. Histological assessment of augmented jaw bone utilizing a new collagen barrier membrane compared to a standard barrier membrane to protect a granular bone substitute material. Clin Oral Implant Res 2002;13: 587-94.

22. Simion M, Scarano A, Gionso L, Piatelli A. Guided bone regeneration using resorbable and nonresorbable membranes: a comparative histologic study in humans. 1996;11:735-42.

23. Chiapasco M, Abati S, Romero E, Vogel G. Clinical outcome of autogenous bone blocks or guided bone regeneration with e-PTFE membranes for the reconstruction of narrow edentolous ridges. Clin Oral Implants Res 1999;10: 278-88. 
24. Coulthard P, Esposito M, Jokstad A, Worthington HV. Interventions for replacing missing teeth: bone augmentation techniques for dental implant treatment. Cochrane Database Syst Rev 2006;CD003607.

25. Tawil G, Mawla M. Sinus floor elevation using a bovine bone mineral (Bio-Oss) with or without the concomitant use of a bilayered collagen barrier (Bio-Gide): a clinical report of immediate and delayed implant placement. Int J Oral Maxillofac Implants 2001;16:713-21.

26. Trombelli L Farina R, Marzola A, Itro A, Calura G. GBR and autogenous cortical bone particulate by bone scraper for alveolar ridge augmentation: a 2-case report. Int J Oral Maxillofac Implants 2008;23:11-6.

27. Pallesen L, Schou S, Aaboe M, Hjorting-Hansen E, Nattestad A, Melsen $\mathrm{F}$. Influence of particle size of autogenous bone grafts on the early stages of bone regeneration: a histologic and stereologic study in Rabbit calvarium. Int J Oral Maxillofac Implants 2002;17:498-506.

28. Hallman M, Zetterqvist L. A 5-year prospective follow-up study of implantsupported fixed prostheses in patients subjected to maxillary sinus floor augmentation with an 80:20 mixture of bovine hydroxyapatite and autogenous bone. Clin Implant Dent Relat Res 2004;6:82-9.

29. Hallman M, Lundgren S, Sennerby L. Histologic analysis of clinical biopsies taken 6 months and 3 years after maxillary sinus floor augmentation with $80 \%$ bovine hydroxyapatite and $20 \%$ autogenous bone mixed with fibrin glue. Clin Implant Dent Relat Res 2001;3:8796.

30. A clinical histologic study of bovine hydroxyapatite in combination with autogenous bone and fibrin glue for maxillary sinus floor augmentation. Results after 6 to 8 months of healing. Hallman M, Cederlund A, Lindskog S, Lundgren S, Senneby L. Clin Oral Implants Res 2001;12:135-43.

31. Hallman M, Sennerby L, Lundgren S. A clinical and histologic evaluation of implant integration in the posterior maxilla after sinus floor augmentation with autogenous bone, bovine hydroxyapatite, or a 20:80 mixture. Int J Oral Maxillofac Implants 2002;17:635-43.

32. Simion M, Fontana F, Rasperini G, Maiorana C. Vertical ridge augmentation by expandedpolytetrafluoroethylene membrane and a combination of intraoral autogenous bone graft and deproteinized anorganic bovine bone (Bio Oss). Clin Oral Implant Res 2007;18:620-9.
33. Collins TA, Brown GK, Johnson N, Massey JA, Nunn BD. Team management of atrophic edentulism with autogenous inlay, veneer and splits grafts and endosseus implants: case reports. Quintessence Int 199;26:79-93.

34. Clavero ], Lundgren S. Ramus or chin grafts for maxillary sinus inlay and local onlay augmentation: comparison of donor site morbidity and complications. Clin Implant Dent Relat Res 2003;5:154-60.

35. Silva FM, Cortez AL, Moreira RW, Mazzonetto R. Complications of intraoral donor site for bone grafting prior to implant placement. Implant Dent 2006;15:420-6.

36. Von Arx T, Buser D. Horizontal ridge augmentation using autogenous block grafts and the guided bone regeneration technique with collagen membranes: a clinical study with 42 patients. Clin Oral Implant Res 2006;17:359-66.

37. Barone A, Covani U. Maxillary alveolar ridge reconstruction with nonvascularized autogenous block bone: clinical results. J Oral Maxillofac Surg 2007;65:2039-46.

38. McCarthy C, Patel RR, Wragg PF, Brook TM. Dental implants and onlay bone grafts in the anterior maxilla: analysis of clinical outcome. Int J Oral Maxillofac Implants 2003;18:238-41.

39. Proussaefs P, Lozada J, Kleinman A, Rohrer M.The use of ramus autogenous block grafts for vertical alveolar ridge augmentation and implant placement: a pilot study. Int J Oral Maxillofac Implants 2002;17:23848.

40. Laman E, Patzakis M, Roidis N, Shepherd L, Holtom P. Comparison of anterior and posterior iliac crest bone grafts in terms of harvest-site morbidity and functional outcomes. J Bone Joint Surg Am 2002;84:71620.

41. Izuka T, Smolka W, Hallermann W, Mericske-Sten R. Extensive augmentation of the alveolar ridge using autogenous calvarial split bone grafts for dental rehabilitation. Clin Oral Implants Res 2004;15:60715.

42. Crespi R, Vinci R, Cappré P, Gherloni E, Romanos GE. Calvarial versus iliac crest for autologous bone graft material for a sinus lift procedure: a histomorphometric study. Int J Oral Maxillofac Implants 2007;22: 527-32. 